\title{
Green Synthesis ZnO/TiO2 for High Recyclability Rapid Sunlight Photodegradation Textile Dyes Applications
}

\section{Erviani Rusman}

Hasanuddin University

Heryanto Heryanto

Hasanuddin University

Ahmad Nurul Fahri

Hasanuddin University

Inayatul Mutmainna

Hasanuddin University

Dahlang Tahir ( $\nabla$ dtahir@fmipa.unhas.ac.id)

Universitas Hasanuddin https://orcid.org/0000-0002-8241-3604

\section{Research Article}

Keywords: green synthesis, composite $\mathrm{ZnO} / \mathrm{TiO} 2$, photocatalytic degradation, high recyclability, textile dye

Posted Date: April 13th, 2021

DOl: https://doi.org/10.21203/rs.3.rs-414953/v1

License: (c) (1) This work is licensed under a Creative Commons Attribution 4.0 International License. Read Full License 


\title{
Green Synthesis $\mathrm{ZnO} / \mathrm{TiO}_{2}$ for High Recyclability Rapid Sunlight Photodegradation Textile Dyes Applications
}

Erviani Rusman, Heryanto Heryanto, Ahmad Nurul Fahri, Inayatul Mutmainna, Dahlang Tahir* Department of Physics, Hasanuddin University, Makassar 90245, Indonesia

Corresponding authors email:*dtahir@fmipa.unhas.ac.id

Telp./Fax: +62-411-587634

\begin{abstract}
Composite $\mathrm{ZnO} / \mathrm{TiO}_{2}$ have been successfully synthesized by green synthesis method with various calcination temperature $500^{\circ} \mathrm{C}, 600^{\circ} \mathrm{C}, 700^{\circ} \mathrm{C}$, and $800^{\circ} \mathrm{C}\left(\mathrm{TiO}_{2}\right.$ concentrations: 2.5 $\mathrm{g}$ and $5 \mathrm{~g}$ ) for photocatalyst application. In this study, Calopogonium mucunoides leaf extract was used as reducing and stabilizing agent. The synthesized composites were characterized by using Fourier Transform Infra-Red (FTIR), X-Ray Diffraction (XRD), and UV-Visible spectroscopy. The XRD spectra shows the hexagonal phase with wurtzite structure of $\mathrm{ZnO}$ and anatase for $\mathrm{TiO}_{2}$. The best degradation performance is $98.26 \%$ (only $10 \mathrm{~min}$ ) for $\mathrm{ZnO} / \mathrm{TiO}_{2}(5 \mathrm{~g}$ ) with calcination temperature is $800^{\circ} \mathrm{C}$. This is due to the highest distance between two optical phonon mode $\Delta(\mathrm{LO}-\mathrm{TO})$ and lowest attenuating and propagating constant. The composite $\mathrm{ZnO} / \mathrm{TiO}_{2}$ shows high potentials photodegradation of organic dyes with the high stable recyclability up to 5 cycles (>95\%) only for every 15 minutes. High potentials for applicability with the concept environmentally friendly principles and stability for circular chemistry, and efficiency of use the energy and chemicals.
\end{abstract}

Keywords: green synthesis, composite $\mathrm{ZnO} / \mathrm{TiO}_{2}$, photocatalytic degradation, high recyclability, textile dye.

\section{INTRODUCTION}


Hazardous contaminants in wastewater are affected by the textile industries, cosmetics manufacturing, pharmaceutical, metals industries, paper making, and agricultural industries [1-3]. Azo dye is a hazardous pollutant that contains $(-\mathrm{N}=\mathrm{N}-)$ bond and phenyl or naphthyl group [4-6]. They are producing aromatic amines during the decomposition process and potentially cause carcinogenic and mutagenic. On the other hand, the presence of azo dye in water causes severe effects on clean water availability and the environment [5-8]. The type of azo dyes is a mono-azo dye (methylene blue, methylene orange, AO7 (acid orange 7)), diazo dye (congo red, 6B (direct lake blue)), and poly azo dyes (direct black BN) [6]. One of the most widely used azo dye is Congo Red (CR). CR is used in processing textile, paper, cosmetic, and pharmaceutical industries $[9,10]$. Those dye are difficult to degrade to be a severe issue for environmental and human health. The increased contaminant compounds in wastewater are interested researchers in finding the polluted water treatment method to provide clean and healthy water [11].

Water purification methods were varied through a physical, biological, and chemical process $[12,13]$. The photocatalyst is one of the most effective and simple techniques used in water treatment because it removes organic contaminants easily [11, 14,15]. Green synthesis is used as an alternative method to produce nanoparticles for photocatalyst applications. It has several advantages, such as eco-friendly, and it does not produce second contaminants [3]. This method used extracts of various plants as reducing or stabilizing agents. Plant extract contains phytochemicals that act as bioreduction materials for capping agents in particular nanoparticles' synthesis process [16]. The reported materials nanoparticles have been produced by using green synthesis are: $\mathrm{Au}, \mathrm{Ag}, \mathrm{Pt}, \mathrm{Pd}, \alpha-\mathrm{Fe}_{2} \mathrm{O}_{3}, \mathrm{CeO}_{2-}, \mathrm{ZnO}, \mathrm{TiO}_{2}, \mathrm{ZrO}_{2}$, and $\mathrm{SnO}_{2}$ [19-22]. $\mathrm{TiO}_{2}$ and $\mathrm{ZnO}$ are 
chemically stable semiconductors that can produce an active charge during irradiation by light with suitable wavelengths $[12,23,24]$. Zinc oxide is n-type semiconductor with high excitation binding energy, bandgap width $(3,37 \mathrm{eV}$ for anatase phase), biocompatibility, and it is more active when irradiation by visible light. Irradiation process for $\mathrm{ZnO}$ will create electron-hole by gain energy of electron for exciting to the conduction band [1]. The electron at the conduction band moves easily to the valence band by the recombination processes. The heterostructure method is effective approach to control and minimize the recombination rate in $\mathrm{ZnO}$ consequently increase the charge carrier lifetime [25-28].

The $\mathrm{TiO}_{2}$ is an effective semiconductor that combines with $\mathrm{ZnO}$ nanoparticles displays improvement in photocatalytic activities [29-35]. $\mathrm{TiO}_{2}$ has higher efficiency as a photocatalytic because it is responsive to the visible spectrum with bandgap $3.2 \mathrm{eV}$ [36-41]. It is using as a photocatalytic due to its good optical properties, low cost, and high chemical stability [40-42]. The catalyst was used for photodegradation of chemical or organic pollutants in wastewater under visible irradiation $[43,44]$. Doping $\mathrm{TiO}_{2}$ with metals or non-metal ions will increase the visible light absorbance capacity or reactivity in the UV wavelength $[45,46]$. The previous reports for $\mathrm{ZnO} / \mathrm{TiO}_{2}$ as a photocatalysis with various synthesized methods are: $\mathrm{ZnO} / \mathrm{TiO}_{2}$ nanohybrids by using a hydrothermal method for $\mathrm{MB}$, R6G, OTC degradation [1], $\mathrm{ZnO} / \mathrm{TiO}_{2}$ by using solid-state for quinoline degradation [29], $\mathrm{ZnO} / \mathrm{TiO}_{2}$ by using sol-gel for dye degradation of methylene blue $[13,35], \mathrm{ZnO}$ and $\mathrm{TiO}_{2}$ commercial for phenothiazine decolorization [36], and $\mathrm{ZnO} / \mathrm{TiO}_{2}$ thin film by using the hydrothermal method for orange $\mathrm{G}$ degradation [10]. However, the green, appropriate, and efficient photocatalysts materials that can be easily integrated into wastewater plants and reused for real 
applications is crucial. The principles process of synthesized these photocatalysts materials should be environmentally friendly, circular chemistry, and increasing the efficiency of the use of energy and chemicals.

For environmentally friendly materials, we synthesize $\mathrm{ZnO} / \mathrm{TiO}_{2}$ using Calopogonium mucunoides leaf extract by green method. Calopogonium mucunoides is a legume and easily grow were impacting agricultural if growth uncontrolled and seminatural ecosystems which becoming an environmental problem mainly in Indonesia. By using this type of a legume for photocatalyst, means that contributes to the green environment, low-cost fabrication, efficient, recyclable, and applicability in short time to produce clean water from decontaminant. In this study, a facile, suitable for massproductive, green, and cost-effective method for the fabrication of nanohybrid $\mathrm{ZnO} / \mathrm{TiO}_{2}$ photocatalyst for enhanced visible-light was developed. The process of photocatalyst materials potentials to be holistically integrates with environmentally friendly principles, circular chemistry, and efficiency of use the energy and chemicals [47-49].

The $\mathrm{ZnO} / \mathrm{TiO}_{2}$ composites for concentration of $\mathrm{TiO}_{2}$ are $2.5 \mathrm{~g}$ and $5 \mathrm{~g}$, and various calcination temperatures $\left(500^{\circ} \mathrm{C}, 600^{\circ} \mathrm{C}, 700^{\circ} \mathrm{C}\right.$, and $\left.800^{\circ} \mathrm{C}\right)$ characterized by using XRD, FTIR, and UV-Vis spectroscopy. The XRD spectra used for analysis the structural properties and FTIR spectra for the optical properties in the form of the refractive index $(n)$ and extinction coefficient $(k)$ by applying Kramers Kronig $(\mathrm{KK})$ relation. The longitudinal and transversal optical phonon mode, the complex dielectric function (real part $\left(\varepsilon_{1}\right)$ and imaginary part $\left.\left(\varepsilon_{2}\right)\right)$, energy loss function $(\operatorname{Im}(-1 / \varepsilon))$, and the optical absorption coefficient were determined from the $n$ and $k$. The photocatalyst efficiency for degradation of CR were analysis using UV-Vis spectrometer spectra. 
High recyclability of the $\mathrm{ZnO} / \mathrm{TiO}_{2}$ composites as catalyst in photodegradation processes are also reported in this study.

\section{EXPERIMENTAL}

\section{Materials and Preparation Sample}

Calopogonium mucunoides (CM) leaves were taken from the Enrekang district, South Sulawesi, Indonesia. Zinc acetate dihydrate $\left(\mathrm{Zn}\left(\mathrm{CH}_{3} \mathrm{COO}\right)_{2} \cdot 2 \mathrm{H}_{2} \mathrm{O}\right)$ (Merck), titanium dioxide $\left(\mathrm{TiO}_{2}\right)$ (Merck), and natrium hydroxide $(\mathrm{NaOH})(\mathrm{Merck})$, and congo red $\left(\mathrm{C}_{32} \mathrm{H}_{22} \mathrm{~N}_{6} \mathrm{Na}_{2} \mathrm{O}_{6} \mathrm{~S}_{2}\right)$ (Merck).

The CM leaves were washed several times by distilled water to remove debris and dirt, then dry them at room temperature for one week. The leaves were powdered using blender and sieved the powder with 100 Mesh for uniform size. The extract was prepared by adding $5 \mathrm{~g}$ of $\mathrm{CM}$ leaves powder in $100 \mathrm{ml}$ distilled water and stirred at $80^{\circ} \mathrm{C}$ for 20 minutes. It was filtered with Whatman No.1 filter paper. The filtrate was used for synthesis $\mathrm{ZnO} / \mathrm{TiO}_{2}$, for more detail illustration of synthesized processes see

\section{Figure 1.}

\section{Synthesis of ${\mathrm{ZnO} / \mathrm{TiO}_{2}}_{2}$}

Sol gel method was used for green synthesis $\mathrm{ZnO} / \mathrm{TiO}_{2}$. The solution prepared with $20 \mathrm{ml} \mathrm{CM}$ leaf extracts, $80 \mathrm{ml}$ distilled water, and $5 \mathrm{~g} \mathrm{Zn}\left(\mathrm{CH}_{3} \mathrm{COO}\right)_{2} \cdot 2 \mathrm{H}_{2} \mathrm{O}$ as a precursor. It was stirred at constant temperature $95^{\circ} \mathrm{C}$ and speed $500 \mathrm{rpm}$. After 15 minutes heated, $\mathrm{TiO}_{2}$ was added to the zinc oxide solution. $\mathrm{TiO}_{2}$ solution was prepared $2.5 \mathrm{~g}$ and $5 \mathrm{~g} \mathrm{TiO}_{2}$ powder by added $10 \mathrm{ml}$ distilled water, then homogenized for 5 minutes by constant stirring at $200 \mathrm{rpm}$ using magnetic stirrer. $\mathrm{NaOH}$ was added 
dropwise to the solution till $\mathrm{pH}$ 7. The paste was formed after continuous heating and stirring for overnight. The sample paste was evaporated at $80^{\circ} \mathrm{C}$ for 10 hours and continue calcined for 2 hours at the temperature $500^{\circ} \mathrm{C}, 600^{\circ} \mathrm{C}, 700^{\circ} \mathrm{C}$, and $800^{\circ} \mathrm{C}$ to obtain $\mathrm{ZnO} / \mathrm{TiO}_{2}$ powder, the illustration procedure as shown in Figure 2.

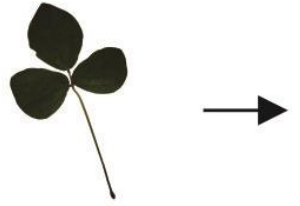

Calopogonium mucunoides

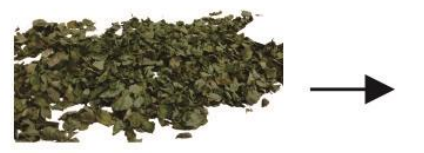

Dried the leaves

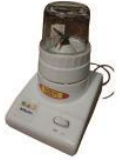

Blend

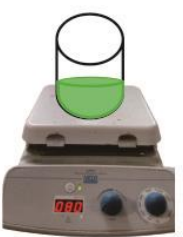

Stirring at $80^{\circ} \mathrm{C}$ for 20 minutes

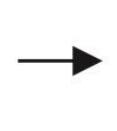

Filtered by using 100 Mesh

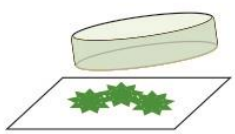

Calopogonium mucunoides leaf extract

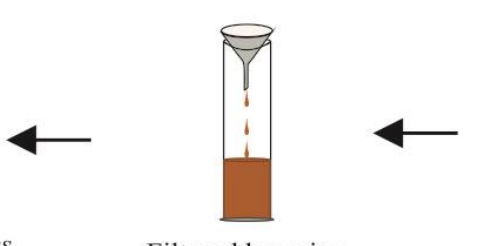

Filtered by using whatman paper No.1

wher

Figure 1. Schematic illustration for extraction of Calopogonium mucunoides leaves
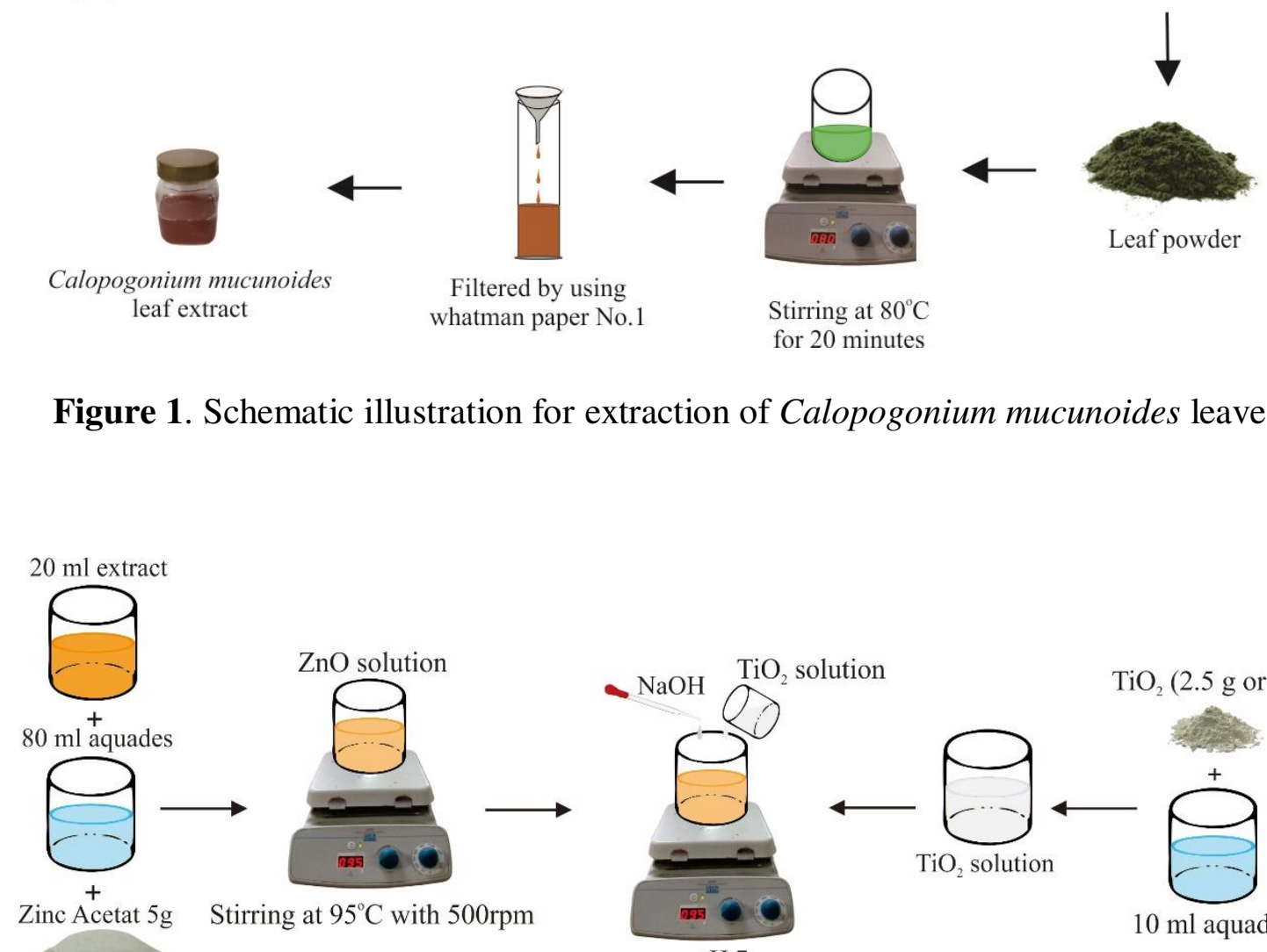

Lear powder
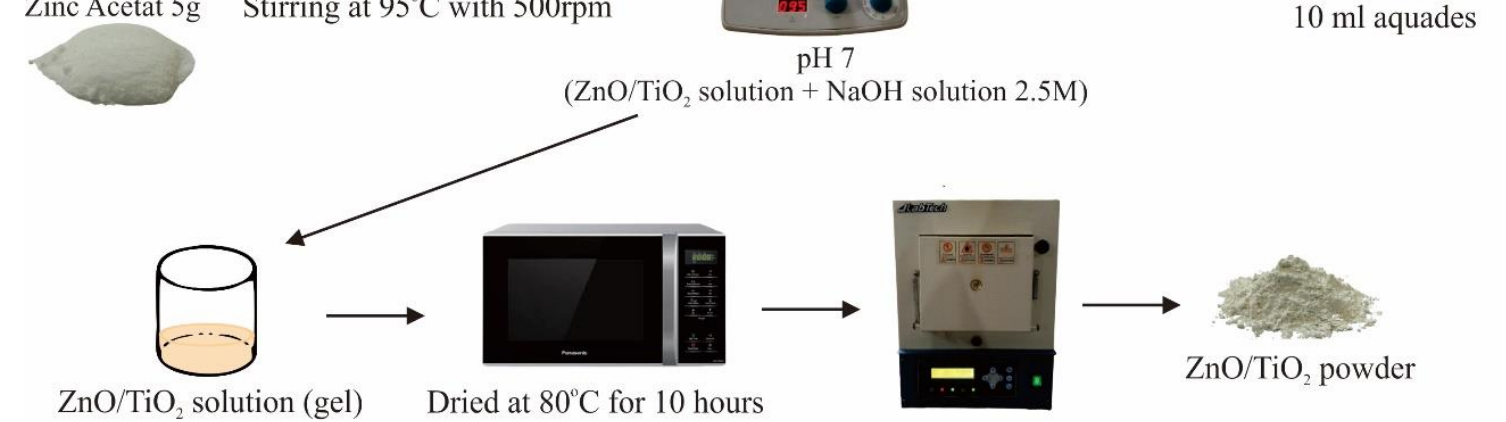

$\mathrm{ZnO} / \mathrm{TiO}_{2}$ solution (gel)

Dried at $80^{\circ} \mathrm{C}$ for 10 hours
Calcined for 2 hours

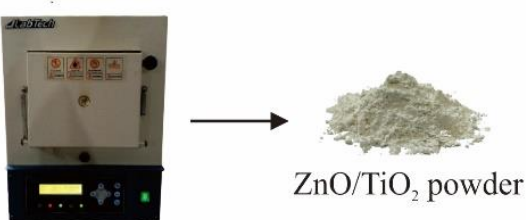




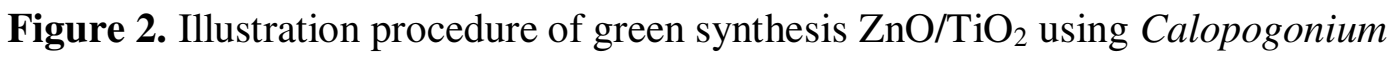
mucunoides leaf extract

\section{Characterization}

The synthesized powder was characterized by XRD spectroscopy, FTIR spectroscopy, and UV-Vis spectrophotometer. XRD spectroscopy (Shimadzu 700) with CuKa radiation at wavelength $(\lambda) 1.54 \AA\left(25^{\circ} \leq 2 \theta \leq 65^{\circ}, 40 \mathrm{kV}, 30 \mathrm{~mA}\right.$, scan rate 2 $\mathrm{min}^{-1}$, step size $0.02^{\circ}$ ) was used to determine the structure and crystallite size of the samples by using Debye Scherrer formula. Fourier Transform Infra-Red Spectroscopy (FTIR Spectroscopy) (IRPrestige-21 (Shimadzu Corp.)) to analyze the functional groups that present and optical properties of the samples. UV-Vis spectrophotometer (Shimadzu UV-Vis Spectrophotometer UV-1800) was used to study the photocatalytic activity of CR.

\section{Photocatalytic Mechanism}

The photocatalytic degradation procedure consisted of adding $0.02 \mathrm{~g}$ of $\mathrm{ZnO} / \mathrm{TiO}_{2}$ powder into $100 \mathrm{ml}$ of CR solution (40 mg/L). The solution was stirred and exposed to light using 300W Osram Tungsten Halogen lamp as a light source. To analyze the CR concentration after degradation process, the solution was carried out every 5 minutes and filtered it. Concentration of the solution after the degradation process was determined by using UV-Vis spectrophotometer and the percentage of degradation determined by:

$$
\mathrm{D}(\%)=\left(\frac{\mathrm{C}_{0}-\mathrm{C}_{\mathrm{t}}}{\mathrm{C}_{0}}\right) \times 100 \%
$$


where $\mathrm{D}(\%)$ is the percentage of degradation, $\mathrm{C}_{0}$ is the initial concentration (at $\mathrm{t}$ is 0 $\min$ ), and $\mathrm{C}_{\mathrm{t}}$ is the concentration after time irradiation $t$ min.

The recyclability of composite in photodegradation was studied by using $\mathrm{ZnO} / \mathrm{TiO}_{2}(2.5 \mathrm{~g})$ at temperature $500^{\circ} \mathrm{C}$. The $0.04 \mathrm{~g}$ of $\mathrm{ZnO} / \mathrm{TiO}_{2}$ was added into $100 \mathrm{ml}$ CR solution (40 mg/L). The solution was stirred at $150 \mathrm{rpm}$ by using magnetic stirrer and it was irradiated for 15 minutes. The solution was filtered, and the concentration was analyzed by using UV-Vis spectrophotometer. The composite was washed with distilled water and centrifuged at $1500 \mathrm{rpm}$ within 5 minutes. These steps were applied repeatedly for 5 times. The sediment was dried at $80^{\circ} \mathrm{C}$ within 10 minutes. Dried composite was added back into $100 \mathrm{ml} \mathrm{CR}$ solution. It was repeated for five cycles.

\section{RESULTS AND DISCUSSION}

\section{XRD analysis}

The XRD spectra were used to identify the crystalline phase of composites $\mathrm{ZnO} / \mathrm{TiO}_{2}$ extracted by green synthesis mediated by Calopogonium mucunoides leaf. Figure 3 shows XRD diffraction patterns for composite $\mathrm{ZnO} / \mathrm{TiO}_{2}\left(\mathrm{TiO}_{2}\right.$ is $2.5 \mathrm{~g}$ and $5.0 \mathrm{~g})$ at various calcination temperature. For all samples shows several diffraction peaks $2 \theta$ of $\mathrm{ZnO}$ at $31.84^{\circ}, 34.48^{\circ}, 36.36^{\circ}, 47.68^{\circ}, 56.74^{\circ}$, and $62.98^{\circ}$ which correspond to the crystal planes (100), (002), (101), (102), (110), and (103) based on JCPDS card no: 36-1451 [50]. The presence of $\mathrm{TiO}_{2}$ in the composite $\mathrm{ZnO} / \mathrm{TiO}_{2}$ was confirmed by the peaks $2 \theta$ at $25.38^{\circ}, 37.94^{\circ}, 47.64^{\circ}$, and $62.96^{\circ}$ which correspond to the crystal planes (101), (004), (200), and (204) for structure anatase based on JCPDS card no: 21-1272 [51] as can be seen in Figure 3 (a) and for $\mathrm{TiO}_{2}$ is $5 \mathrm{~g}$ in Figure 3 (b). 
Figure 3 (c) and (d) shows enlarger XRD spectra for diffraction peak from $30^{\circ}$ to $37^{\circ}$ for various calcination temperature. It shows there are shifts toward the highest of the diffraction angle for $2.5 \mathrm{gr} \mathrm{TiO}_{2}$ at $600^{\circ} \mathrm{C}$ and $700^{\circ} \mathrm{C}$ due to the lattice reduction and for $800^{\circ} \mathrm{C}$ small shits backward to the lower of the diffraction angle due to the some of the atoms are uniform arrangement and forming new cluster crystal [52-54]. For composite with $5.0 \mathrm{~g} \mathrm{TiO}_{2}$ shows shifts to the higher diffraction angle regularly due to the number of atoms $\mathrm{Ti}$ filled the lattice of $\mathrm{ZnO}$ over than the capacity for the lattice reduction or may due to the large ionic radius of Ti compared with that of $\mathrm{Zn}$ [55].

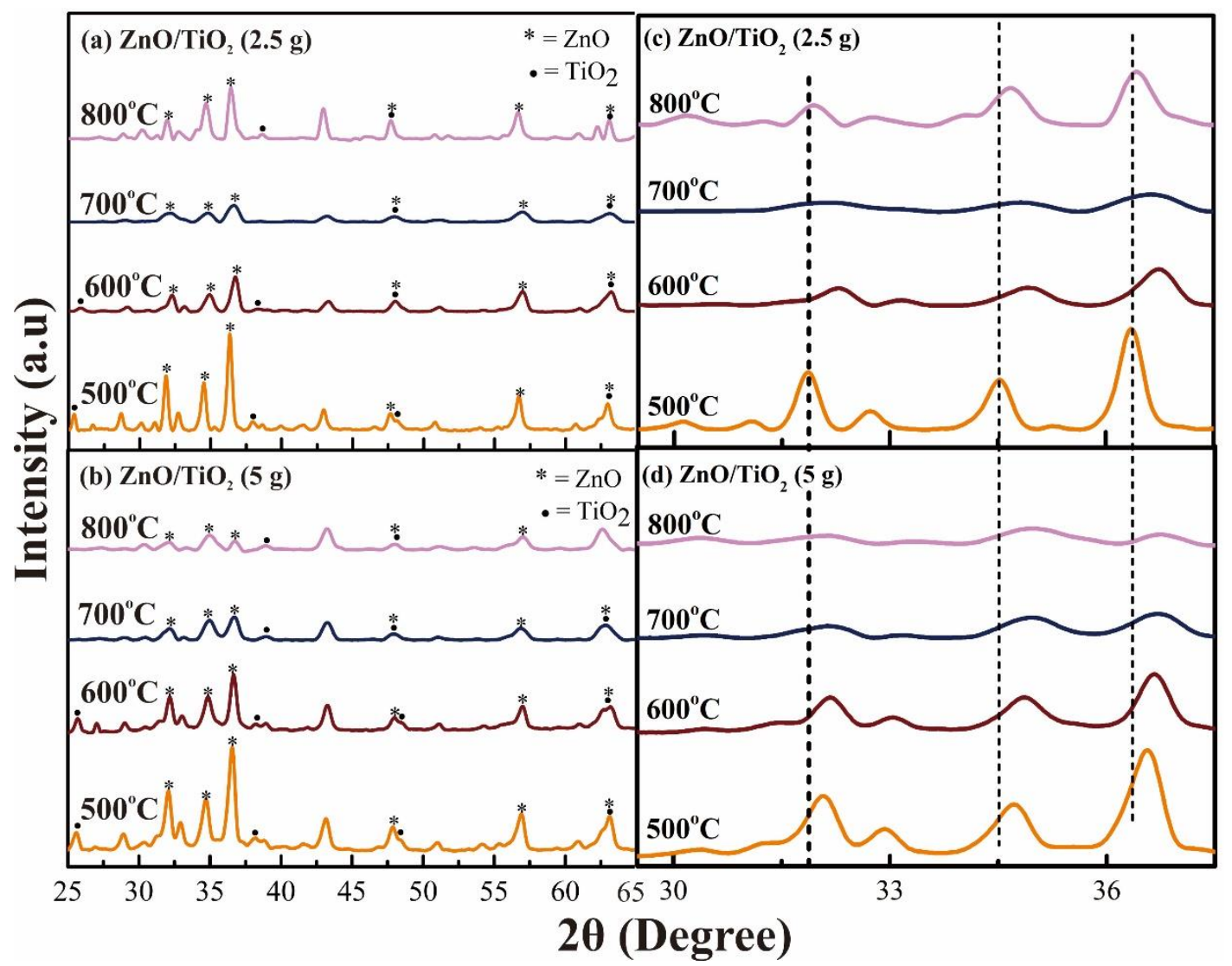

Figure 3. XRD analysis of $\mathrm{ZnO} / \mathrm{TiO}_{2}$ synthesized from Calopogonium mucunoides leaves extract for various calcination temperature $\left(500^{\circ} \mathrm{C}, 600^{\circ} \mathrm{C}, 700^{\circ} \mathrm{C}, 800^{\circ} \mathrm{C}\right)$ and $\mathrm{TiO}_{2}$ concentration $(2.5 \mathrm{~g}$ and $5 \mathrm{~g})$ 
The intensity (101) crystal plane of $\mathrm{TiO}_{2}$ clearly can be seen in composite at the temperature $\leq 600^{\circ} \mathrm{C}$ but for $>600^{\circ} \mathrm{C}$ the intensity peak reduces drastically or almost disappears may due to the phase change from $\mathrm{TiO}_{2}$ to $\mathrm{ZnTiO}_{3}$. In addition, the (102) and (103) planes of $\mathrm{ZnO}$ overlap with the (200) and (204) planes of $\mathrm{TiO}_{2}$. It shows that there is perfect interaction occurs between the lattice of $\mathrm{ZnO}$ and $\mathrm{TiO}_{2}$ to produce $\mathrm{ZnO} / \mathrm{TiO}_{2}$ composite [56]. At the lowest temperature, there are some small peaks that occur at $2 \theta$ : $30.14^{\circ}, 42.96^{\circ}, 50.78^{\circ}$, and $60.70^{\circ}$ correspond to the crystal plane (220), (400), (422), and (440), respectively, identified $\mathrm{ZnTiO}_{3}$ phase based on the JCPDS card No: 39-0190 [57]. For the temperature increases from $500^{\circ} \mathrm{C}$ to $600^{\circ} \mathrm{C}$, the diffraction peaks intensity of $\mathrm{ZnTiO}_{3}$ were decrease and the phase transformation occurred at the temperature $800^{\circ} \mathrm{C}$ clearly can be seen the intensity of $\mathrm{ZnTiO}_{3}$ decreases and $\mathrm{Zn}_{2} \mathrm{TiO}_{4}$ increase. It shows that some of the $\mathrm{ZnTiO}_{3}$ phase were decomposed to forming $\mathrm{Zn}_{2} \mathrm{TiO}_{4}$ phase as can be seen at the diffraction peaks $32.24^{\circ}, 34.90^{\circ}, 36.82^{\circ}$, and $56.96^{\circ}$ based on the JCPDS: 01-073-0578 [11,14,58]. The peak intensities decrease and the width of FWHM increase by increasing the calcination temperature from $600^{\circ} \mathrm{C}$ to $700^{\circ} \mathrm{C}$ may due to the crystallite size or the interatomic spacing decreased [14,59]. 
Table 1. The average crystallite size, dislocation density, and strain determined by the quantitative analysis of XRD spectra in Figure 3.

\begin{tabular}{ccccc}
\hline Sample & $\begin{array}{c}\text { Temperature } \\
\left({ }^{\circ} \mathrm{C}\right)\end{array}$ & $\begin{array}{c}\text { Average crystallite } \\
\text { size }(\mathrm{nm})\end{array}$ & $\begin{array}{c}\text { Dislocation density } \\
\left(\mathrm{nm}^{-2}\right)\end{array}$ & $\begin{array}{c}\text { Strain } \\
(\mathrm{S})\end{array}$ \\
\hline \multirow{2}{*}{${\mathrm{ZnO} / \mathrm{TiO}_{2}}^{2}$} & 600 & 19.99 & 0.0025 & 0.0048 \\
$(2.5 \mathrm{~g})$ & 700 & 11.87 & 0.0071 & 0.0081 \\
& 800 & 7.62 & 0.0172 & 0.0132 \\
& 500 & 17.64 & 0.0032 & 0.0057 \\
\hline $\mathrm{ZnO} / \mathrm{TiO}_{2}$ & 600 & 15.73 & 0.0040 & 0.0062 \\
$(5 \mathrm{~g})$ & 700 & 15.21 & 0.0043 & 0.0063 \\
& 800 & 8.86 & 0.0127 & 0.0111 \\
& 8.94 & 0.0125 & 0.0120 \\
\hline
\end{tabular}

From the XRD spectra in Figure 3 clearly shows relationship between calcination temperatures with the peak intensities. At low calcination temperature $\left(500^{\circ} \mathrm{C}\right)$ the intensity of diffraction peaks are sharp and decrease with increasing the calcination temperature, consequently decrease the crystallite size as can be seen in Table $\mathbf{1}$ calculated from the Debye Scherrer's equation [3,60,61]:

$$
\Gamma=\frac{K \cdot \lambda}{\beta \cdot \operatorname{Cos} \theta}
$$

where $\Gamma$ is the crystallite size, $\theta$ is the Bragg diffraction angle, $K$ is the constant about $0.9, \lambda$ is the wavelength of X-ray (for $\mathrm{Cu}$ is $1.5406 \AA$ ), and $\beta$ is full width at half-length maximum (FWHM). The average of crystallite size, dislocation density, and strain were shown in the Table $\mathbf{1 .}$

\section{FTIR analysis}




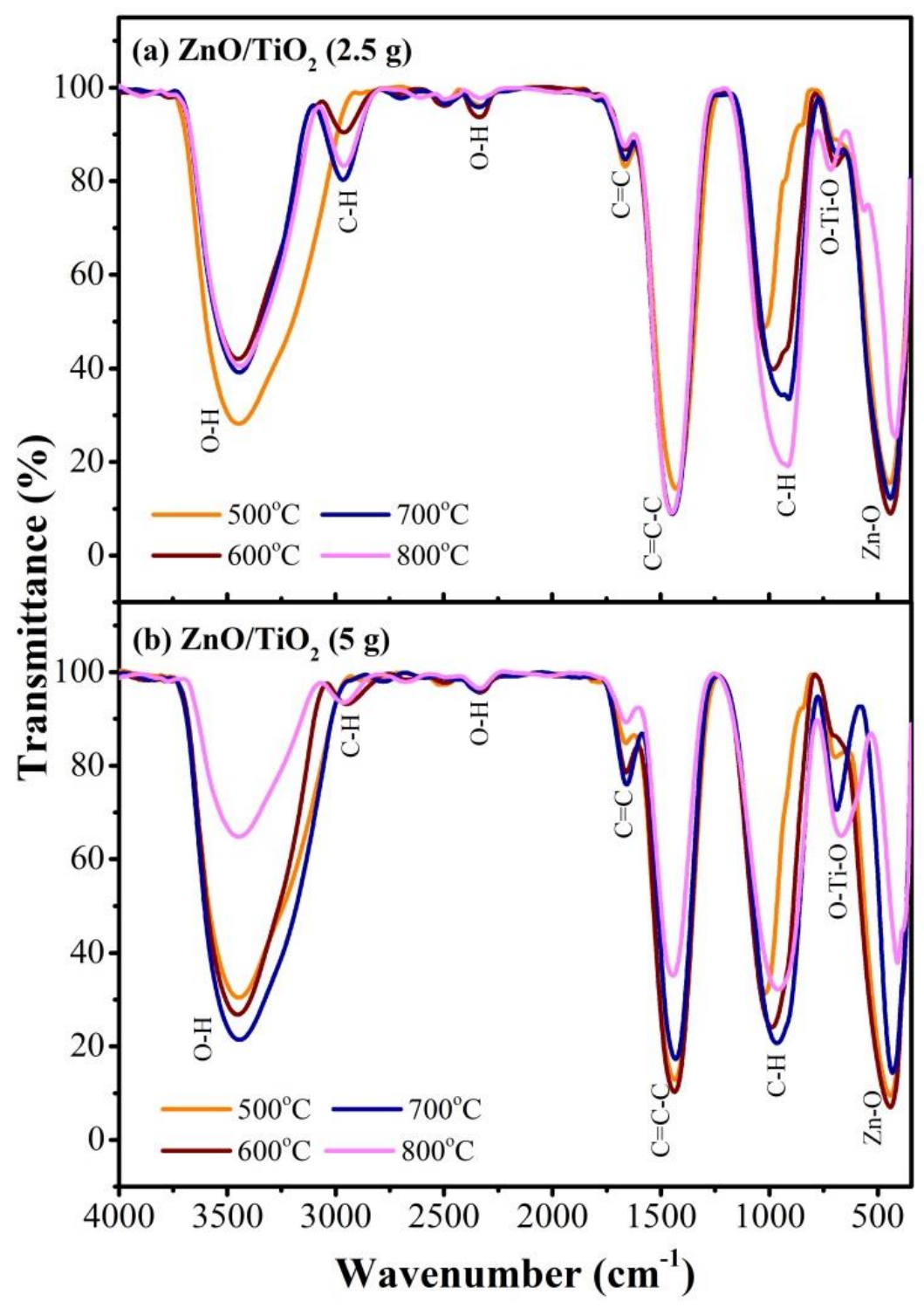

Figure 4. FTIR spectra of $\mathrm{ZnO} / \mathrm{TiO}_{2}$ synthesized from Calopogonium mucunoides leaves extract for various calcination temperature $\left(500^{\circ} \mathrm{C}, 600^{\circ} \mathrm{C}, 700^{\circ} \mathrm{C}, 800^{\circ} \mathrm{C}\right)$ and $\mathrm{TiO}_{2}$ concentration $(2.5 \mathrm{~g}$ and $5 \mathrm{~g})$

Figure 4 shows FTIR spectra at the wavenumber $350-4000 \mathrm{~cm}^{-1}$ for identified the functional groups and vibrational bonds of composite $\mathrm{ZnO} / \mathrm{TiO}_{2}$. The peak $446 \mathrm{~cm}^{-1}$ corresponding to the vibration bond of $\mathrm{Zn}-\mathrm{O}[3,62]$. The peak at $723 \mathrm{~cm}^{-1}$ correspond to the O-Ti-O band [63]. The function group of C-H band at the wave number 1000-1100 
$\mathrm{cm}^{-1}[14]$ and at the wavenumber $1447 \mathrm{~cm}^{-1}$ and $1665 \mathrm{~cm}^{-1}$, there are chemical bonds of $\mathrm{C}=\mathrm{C}-\mathrm{C}$ and $\mathrm{C}=\mathrm{C}$ tensile vibration, respectively $[21,55] . \mathrm{O}-\mathrm{H}$ bond appears at the wavenumber $2504 \mathrm{~cm}^{-1}$ and $3455 \mathrm{~cm}^{-1}$ corresponding to vibration band from suspension of hydroxyl group in adsorbed water [3,64]. A weak infrared peak at $2338 \mathrm{~cm}^{-1}$ probably due to the $\mathrm{CO}_{2}$ vibration bond absorbed during calcination process. The peak at $2968 \mathrm{~cm}^{-1}$ is mainly due to the stretching vibration of $\mathrm{C}-\mathrm{H}$ bond from the absorption of the alkane groups [14].

\section{Optical properties}

The optical properties (refractive index (n) and extinction coefficient (k)) were determined from the quantitative analysis of FTIR spectra by applying K-K relation [65-67]. For the analysis optical properties, we have used only wavenumber in the range from $860 \mathrm{~cm}^{-1}$ to $1115 \mathrm{~cm}^{-1}$ due to the $\mathrm{C}=\mathrm{C}-\mathrm{C}$ bonding which probably come from the green synthesis methods. The FTIR spectra form the equipment is in the form of transmittance $(T(\omega))$, where need to be converted to the reflectance $(R(\omega))[68]$ by the relations:

$$
\begin{aligned}
& A(\omega)=2-\log [T(\omega) \%] \\
& R(\omega)=100-[T(\omega)+A(\omega)]
\end{aligned}
$$

The reflectance $R(\omega)$ as a function of the wavenumber is substitute in the following equations for determining the optical properties (refractive index for real part $\mathrm{n}(\omega)$ and extinction coefficient for imaginary part $\mathrm{k}(\omega))[68]$ :

$$
\begin{aligned}
& n(\omega)=\frac{1-R(\omega)}{1+R(\omega)-2 \sqrt{R(\omega)} \cos \emptyset(\omega)} \\
& k(\omega)=\frac{2 \sqrt{R(\omega)} \cos \emptyset(\omega)}{1+R(\omega)-2 \sqrt{R(\omega)} \cos \emptyset(\omega)}
\end{aligned}
$$


$\varphi(\omega)$ is the phase change from the incident photon beam bombardment to the sample and traveling at the surface down to few atoms at the sample and then reflected photon beam out which calculated by the following equation:

$$
\varphi(\omega)=-\frac{\omega}{\pi} \int_{0}^{\infty} \frac{\ln R\left(\omega^{\prime}\right)-\ln R(\omega)}{\omega^{\prime 2}-\omega^{2}}
$$

For easily computational of by $\varphi(\omega)$, the K-K (Kramers-Kronig) relation was used and the new equation of phase change $\varphi(\omega)$ :

$$
\varphi(\omega)=-\frac{4 \omega_{\mathrm{j}}}{\pi} \Delta \omega \sum_{\mathrm{i}} \frac{\ln (\sqrt{\mathrm{R}(\omega)})}{\omega_{\mathrm{i}}^{2}-\omega_{\mathrm{j}}^{2}}
$$

where $\Delta \omega=\omega_{i+1}-\omega_{i}$ and $\mathrm{j}$ is series of wavenumber, if $\mathrm{j}$ is an odd number, so then $\mathrm{i}$ parts is $2,4,6,8, \ldots, j-1, j+1$ and while wavenumber $\mathrm{j}$ is an even, $\mathrm{i}$ parts is $1,3,5,7, \ldots, \mathrm{j}-1$, $\mathrm{j}+1$. 
(a)

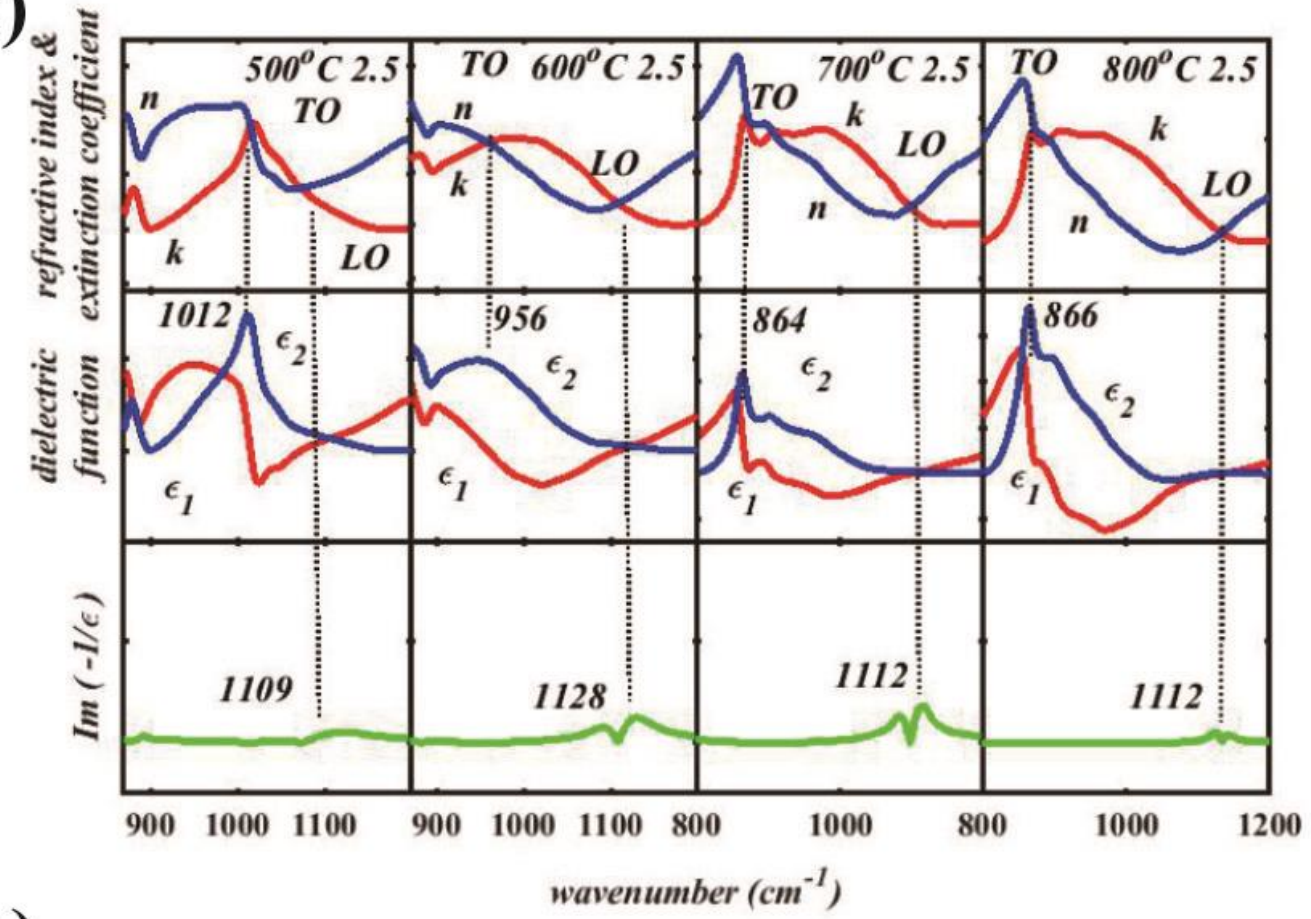

(b)

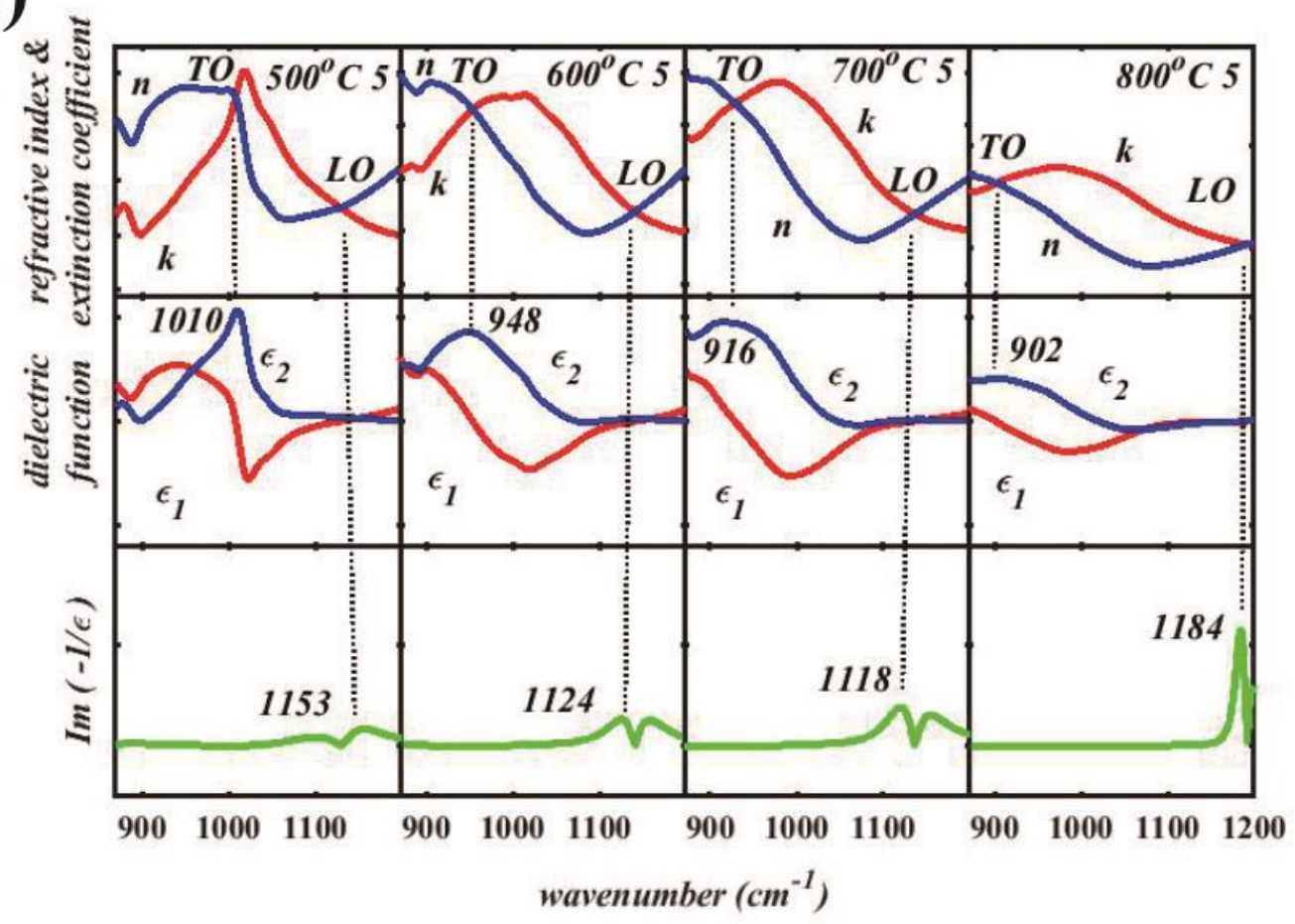

Figure 5. The optical properties (refractive index (n) and extinction coefficient (k)) determined from the FTIR spectra in Figure 4, from the optical properties the dielectric function, the energy loss function $\operatorname{Im}\left(-1 / \varepsilon_{1}(\omega)\right)$ are determined for various calcination temperature for (a) $\mathrm{ZnO} / \mathrm{TiO}_{2}(2.5 \mathrm{~g})$ and (b) $\mathrm{ZnO} / \mathrm{TiO}_{2}(5 \mathrm{~g})$. 
Figure 5 (a and b) shows the intersection at higher wavenumber indicated by LO and intersection point at the lower wavenumber indicated by $\mathrm{TO}$ and the values are presented in Table 2. Figure 5(a) depicts the transverse optical (TO) of $\mathrm{ZnO} / \mathrm{TiO}_{2}(2.5$ g) shifts to the lower wavenumber by increase the calcination temperature up to $700{ }^{\circ} \mathrm{C}$, but for $800^{\circ} \mathrm{C}$ the $\mathrm{TO}$ shifts to the higher wavenumber may due to the effect of the weak strain in the crystal structure. Figure 5(b) shows TO was decreased with increasing the temperature. In this study, the highest distance between the two optical phonon vibration mode $(\Delta(\mathrm{LO}-\mathrm{TO}))$ for $\mathrm{ZnO} / \mathrm{TiO}_{2}(5 \mathrm{~g})$ at $800^{\circ} \mathrm{C}$ may due to some $\mathrm{H}_{2} \mathrm{O}$ loses in the lattice consequently increase optical bandgap [64,69]. The $\Delta(\mathrm{LO}-\mathrm{TO})$ was increased with the increasing the $\mathrm{TiO}_{2}$ concentration at the same calcination temperature but not for $700^{\circ} \mathrm{C}$ may due to the number of defect (dislocation density) increase consequently the atomic bonding unstable and rearrange to form new atomic cluster in the lattice structure $[70,71]$. 
Table 2. Transverse optical (TO) phonon mode, longitudinal optical (LO) phonon mode, and $\Delta(\mathrm{LO}-\mathrm{TO})$

\begin{tabular}{ccccc}
\hline Sample & Temperature $\left({ }^{\circ} \mathrm{C}\right)$ & $\mathrm{TO}\left(\mathrm{cm}^{-1}\right)$ & $\mathrm{LO}\left(\mathrm{cm}^{-1}\right)$ & $\Delta(\mathrm{LO}-\mathrm{TO})\left(\mathrm{cm}^{-1}\right)$ \\
\hline & 500 & 1012 & 1109 & 97 \\
$\mathrm{ZnO} / \mathrm{TiO}_{2}(2.5 \mathrm{~g})$ & 600 & 956 & 1128 & 172 \\
& 700 & 864 & 1112 & 248 \\
& 800 & 866 & 1112 & 246 \\
\hline & 500 & 1010 & 1153 & 143 \\
$\mathrm{ZnO} / \mathrm{TiO}_{2}(5 \mathrm{~g})$ & 600 & 948 & 1124 & 176 \\
& 700 & 916 & 1118 & 202 \\
& 800 & 902 & 1184 & 282 \\
\hline
\end{tabular}

The real part $\left(\varepsilon_{1}\right)$ and imaginary part $\left(\varepsilon_{2}\right)$ of dielectric function functions were calculated from the relation between $n$ and $k$ as follows [66]:

$$
\begin{aligned}
& \varepsilon_{1}(\omega)=\mathrm{n}^{2}(\omega)-\mathrm{k}^{2}(\omega) \\
& \varepsilon_{2}(\omega)=2 \mathrm{n}(\omega) \mathrm{k}(\omega)
\end{aligned}
$$

The main peak position of the imaginary part $\left(\varepsilon_{2}\right)$ and the energy loss function Im $\left(-1 / \varepsilon_{1}(\omega)\right)$ were used for confirmation of the TO and LO phonon vibration modes from the intersection point between $n$ and $k$, respectively. These finding shows consistency result as can be seen in the Figure 5, indicated that the effectiveness of the FTIR spectra for determining optical properties and for identification optical phonon modes. The energy loss function also identified as a plasma frequency as reported in Ref. $[65,66,72]$ from the quantitative analysis of electron spectroscopy [66,73]. The $\Delta(\mathrm{LO}-\mathrm{TO})$ is important parameters to identified stability of the covalent bond and the lattice match in the $\mathrm{ZnO} / \mathrm{TiO}_{2}$ composite [70]. 
The next important parameters are attenuation constant $\alpha$ and propagation constant $\beta$ which determined from the following relations:

$$
\begin{aligned}
& \alpha=\omega \sqrt{\frac{\mu_{0} \varepsilon_{0} \varepsilon_{1(\omega)}}{2}\left[\sqrt{1+\left(\frac{\varepsilon_{2}(\omega)}{\varepsilon_{1}(\omega)}\right)^{2}}-1\right]} \\
& \beta=\omega \sqrt{\frac{\mu_{0} \varepsilon_{0} \varepsilon_{1(\omega)}}{2}\left[\sqrt{1+\left(\frac{\varepsilon_{2}(\omega)}{\varepsilon_{1}(\omega)}\right)^{2}}+1\right]}
\end{aligned}
$$

where $\mu_{0}$ is a constant related to the permeability and $\varepsilon_{0}$ is also constant for permittivity in a free space.

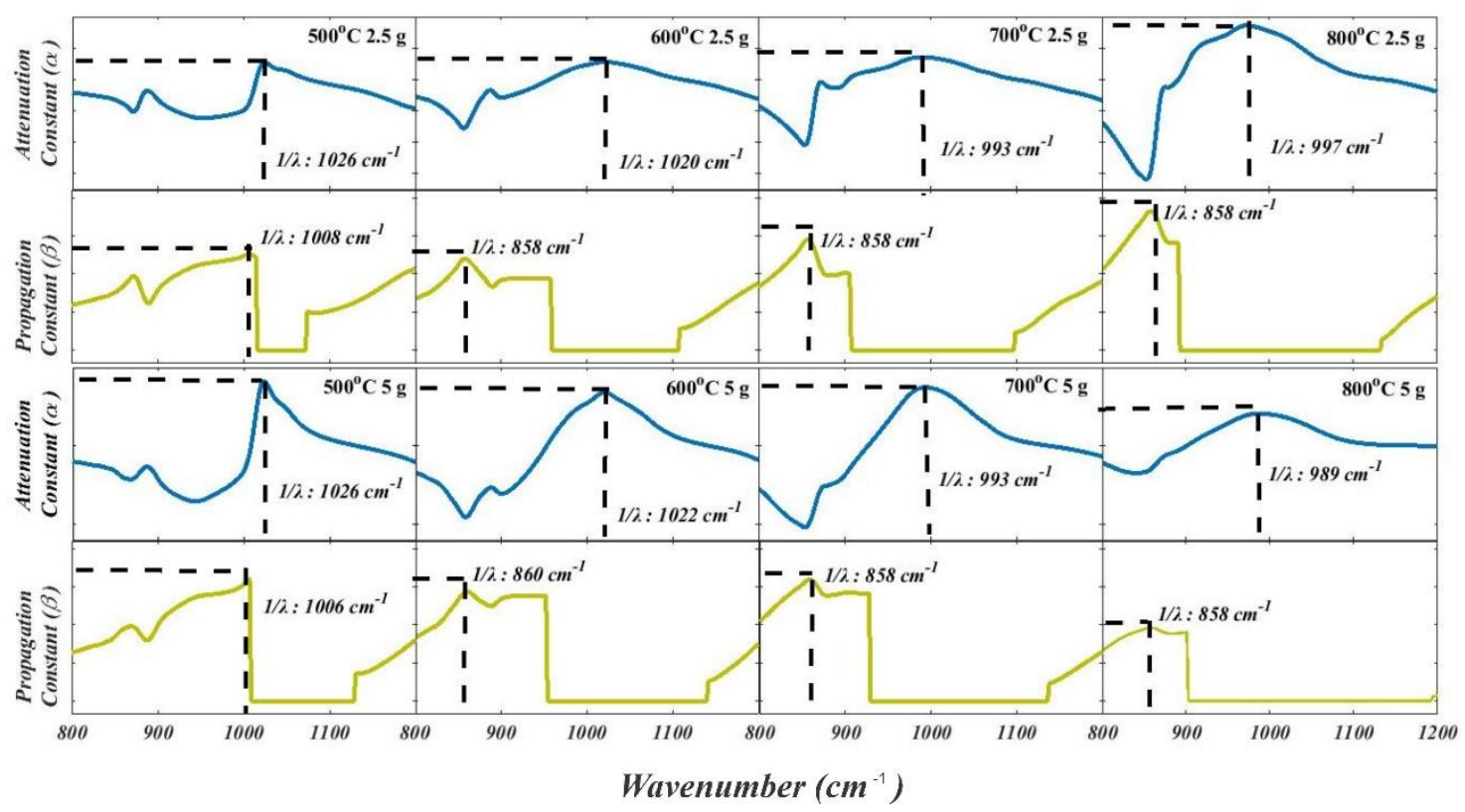

Figure 6. Attenuation constant $(\alpha)$ (first and third rows) and propagation constant $(\beta)$ (second and fourth rows) as a function of the wavenumber for calcination temperature from $500^{\circ} \mathrm{C}$ (left) to $800^{\circ} \mathrm{C}$ (right). First and second rows for $2.5 \mathrm{gr}$ of $\mathrm{TiO}_{2}$ in $\mathrm{ZnO} / \mathrm{TiO}_{2}$ composite and the third and fourth rows for $5 \mathrm{gr}$ of $\mathrm{TiO}_{2}$ in $\mathrm{ZnO} / \mathrm{TiO}_{2}$ composite. 
For 2.5 gr of $\mathrm{TiO}_{2}$ in $\mathrm{ZnO} / \mathrm{TiO}_{2}$ composite shows the attenuation and propagation constant increase with increasing the calcination temperature from $500^{\circ} \mathrm{C}$ (left) to $800^{\circ} \mathrm{C}$ (right) and opposite trend for $5 \mathrm{gr}$ of $\mathrm{TiO}_{2}$ in $\mathrm{ZnO} / \mathrm{TiO}_{2}$ composite as can be seen in Figure 6. The best composite for photocatalyst is for low attenuating and propagating constant, means that the structure will easily suppressing recombination of the charge particle due to the higher strain between the atoms $[52,54]$. In this study shows 5 gr of $\mathrm{TiO}_{2}$ in $\mathrm{ZnO} / \mathrm{TiO}_{2}$ composite high potentials compared than that of $2.5 \mathrm{gr} \mathrm{TiO}_{2}$ in $\mathrm{ZnO} / \mathrm{TiO}_{2}$ composite for the same calcination temperature [64].

\section{Bandgap and Photocatalytic Degradation}




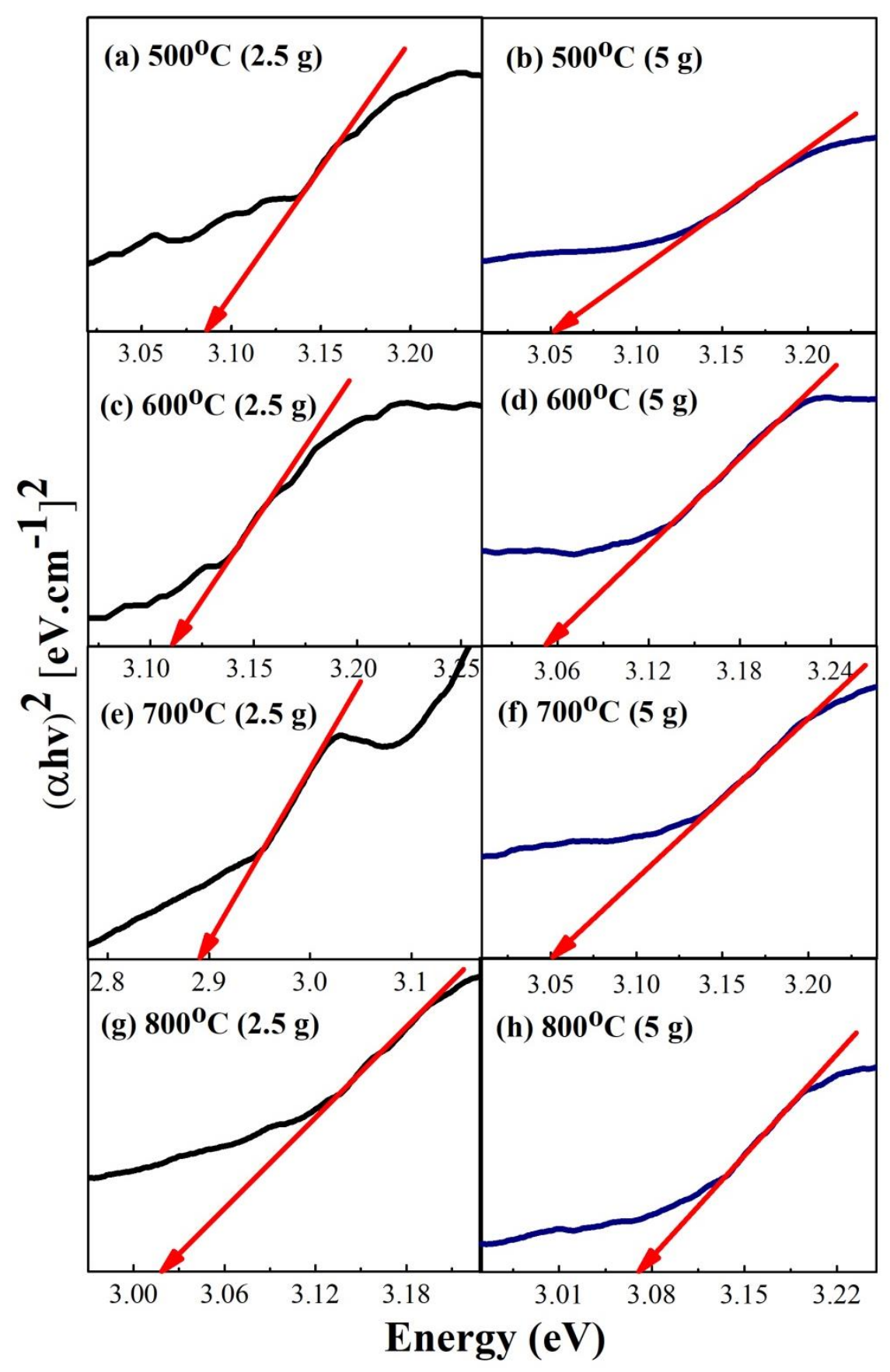

Figure 7. Band gap of $\mathrm{ZnO} / \mathrm{TiO}_{2}$ synthesized from Calopogonium mucunoides leaves extract for various calcination temperature $\left(500^{\circ} \mathrm{C}, 600^{\circ} \mathrm{C}, 700^{\circ} \mathrm{C}, 800^{\circ} \mathrm{C}\right)$ and $\mathrm{TiO}_{2}$ concentration $(2.5 \mathrm{~g}$ and $5 \mathrm{~g})$ 
Band gap of $\mathrm{ZnO} / \mathrm{TiO}_{2}$ composites indicated by the arrows at the absorbance spectra in Figure 7. Band gap values were obtained by using Touch Plot method and the corresponding results are presented in Table 4, which determined by the relation as follows:

$$
(\alpha \mathrm{h} v)^{1 / m}=\mathrm{C}\left(\mathrm{h} v-\mathrm{E}_{g}\right)
$$

where $\alpha$ is absorption coefficient, hv refers to photon energy, $\mathrm{C}$ is band form parameter, $\mathrm{m}=1 / 2$ for the direct allowed transition, and $\mathrm{E}_{\mathrm{g}}$ is band gap energy.

The calcination temperature from $500^{\circ} \mathrm{C}$ to $700^{\circ} \mathrm{C}$, the band gap of composite $\mathrm{ZnO} / \mathrm{TiO}_{2}$ for $5 \mathrm{~g} \mathrm{TiO}_{2}$ is same but for composite with $2.5 \mathrm{~g} \mathrm{TiO}_{2}$ is fluctuates due to the effect of cohesion force between the atoms of $\mathrm{Zn}$ and $\mathrm{Ti}$. For calcination temperature from $700^{\circ} \mathrm{C}$ to $800^{\circ} \mathrm{C}$, the sample for the different concentration of $\mathrm{TiO}_{2}$ shows increases the band gap may due to the effect of particle size and crystal phase in the composite is increase $[14,74]$.

The ability of $\mathrm{ZnO} / \mathrm{TiO}_{2}$ as photocatalytic materials for degradation of $\mathrm{CR}$ was analyzed using UV-Vis spectrophotometer. Figure 8 shows the absorbance spectrum of $\mathrm{CR}$ with $\mathrm{ZnO} / \mathrm{TiO}_{2}$ during irradiation, for the solution can be identified visually or by the absorbance spectra at the wavelength $400-600 \mathrm{~nm}$. The time for every sample to degrade CR was different, it influenced by the ability of charge particle to produce hydroxyl and superoxide radical which play the important roles in photodegradation.

The relation between the percentages of degradation with irradiation times are shown in Figure 9 and the corresponding results of percentage degradation for all sample with various calcination temperature and various $\mathrm{TiO}_{2}$ concentration were shown in Table 3. The efficiency of photocatalyst $\mathrm{ZnO} / \mathrm{TiO}_{2}$ mediated by Calopogonium mucunoides leaves extract is higher than $94 \%$. The highest efficiency is 
$98,26 \%$ that obtained by $\mathrm{ZnO} / \mathrm{TiO}_{2}(5 \mathrm{~g})$ with calcination temperature is $800^{\circ} \mathrm{C}$. It indicates the synthesis composites $\mathrm{ZnO} / \mathrm{TiO}_{2}$ have a great potential for photocatalytic materials.

Photocatalytic activity was affected by some factors: type of photocatalyst material, crystallite size, and agglomeration level. It means that, the photodegradation process may related to the different competing factors [14]. Based on the previous reported which published by Selvi et.al, a diminution of the crystallite size led to an increase in the specific surface area that could enhance the active reaction of the photocatalyst materials [75]. 


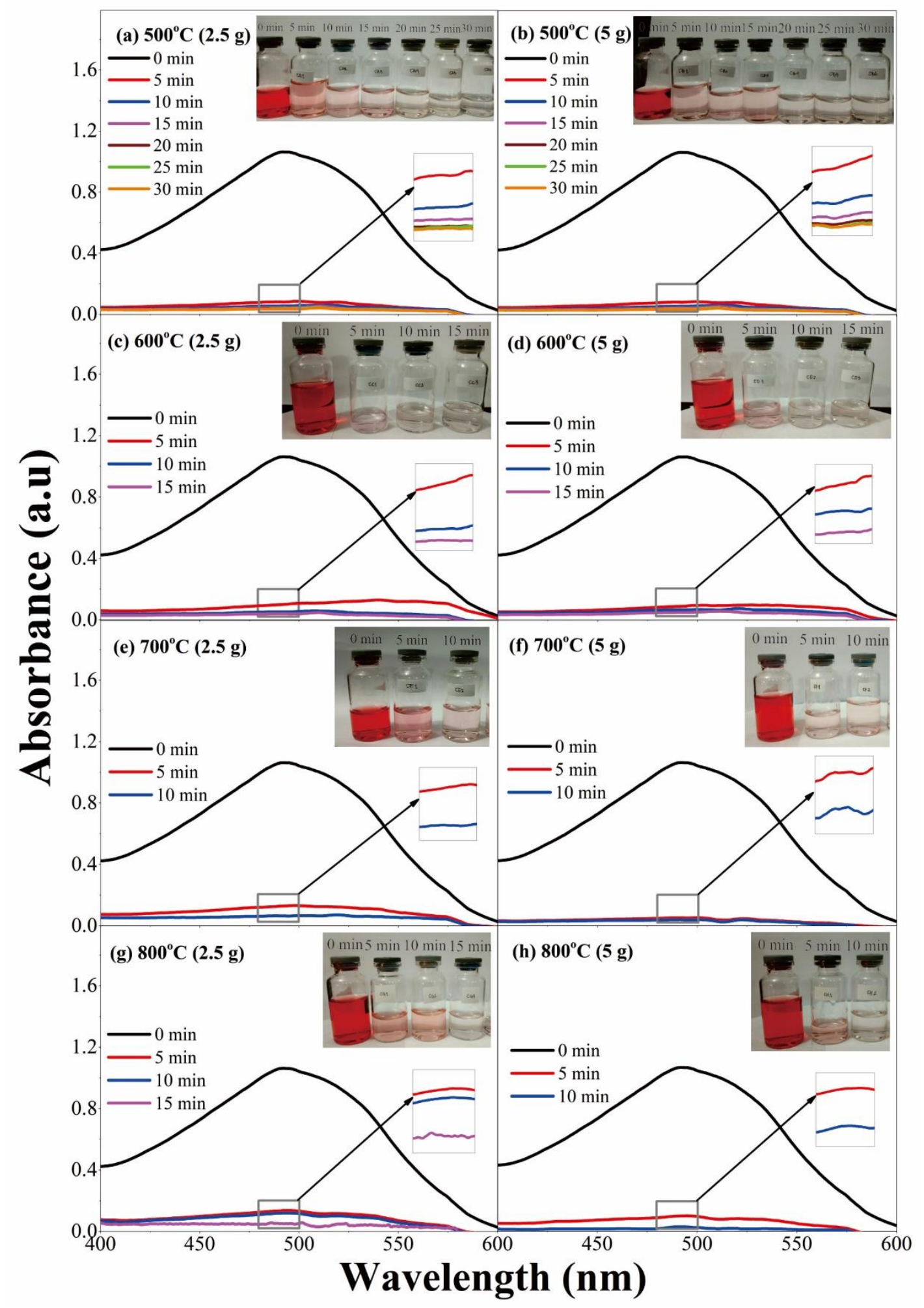

Figure 8. UV-visible absorption spectra of $\mathrm{ZnO} / \mathrm{TiO}_{2}(2.5 \mathrm{~g}$ and $5 \mathrm{~g})$ synthesized from

Calopogonium mucunoides leaves extract for various calcination temperature $\left(500^{\circ} \mathrm{C}\right.$, $600^{\circ} \mathrm{C}, 700^{\circ} \mathrm{C}$, and $\left.800^{\circ} \mathrm{C}\right)$ 

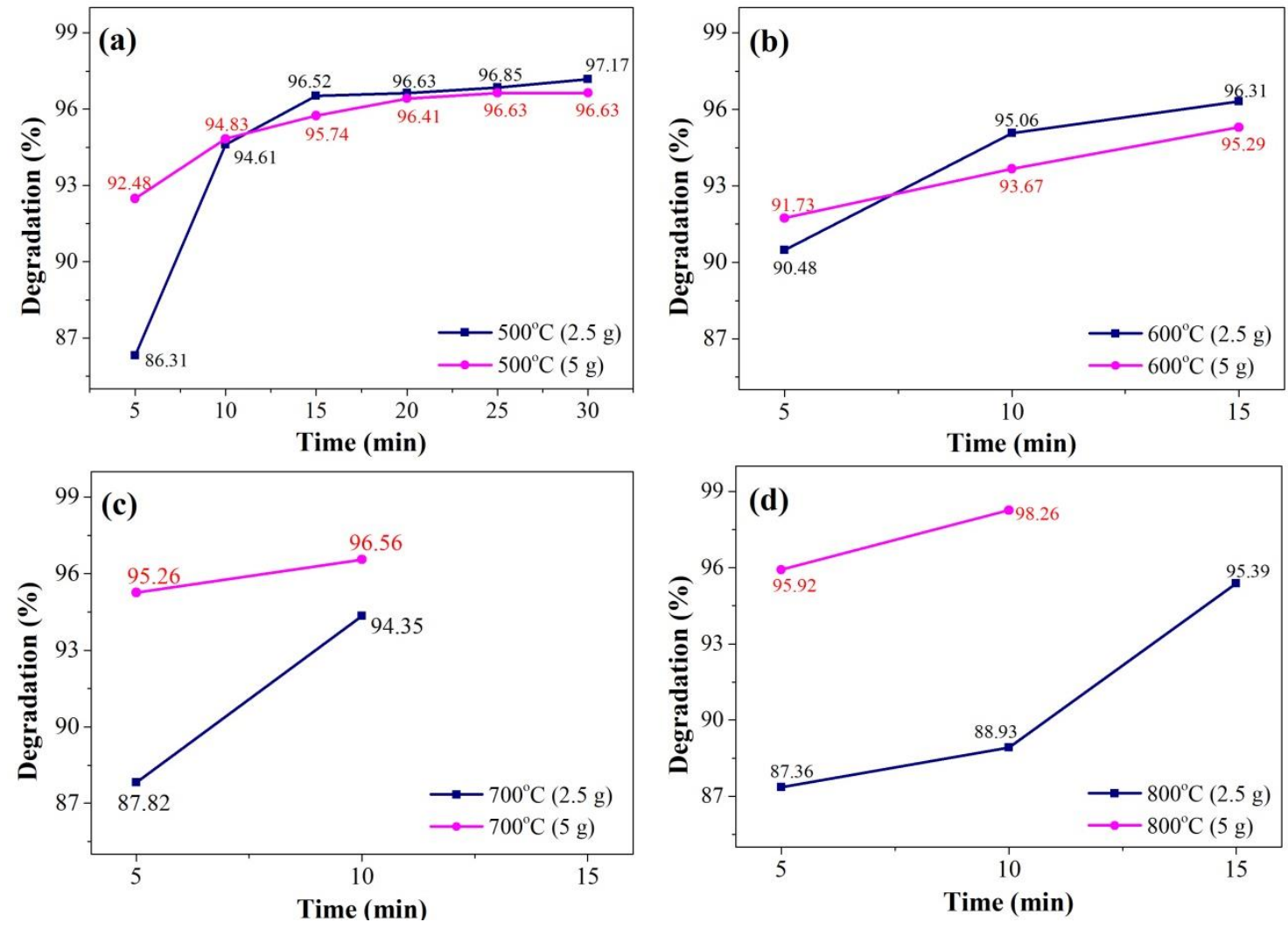

Figure 9. Percentage degradation of CR with the different catalysts (a) $500^{\circ} \mathrm{C}$,

(b) $600^{\circ} \mathrm{C}$, (c) $700^{\circ} \mathrm{C}$, and (d) $800^{\circ} \mathrm{C}$

Table 3. The degradation ability of samples $\mathrm{ZnO} / \mathrm{TiO}_{2}$ to degrade $\mathrm{CR}$ with the different catalysts

\begin{tabular}{cccc}
\hline Sample & Temperature $\left({ }^{\circ} \mathrm{C}\right)$ & $\begin{array}{c}\text { Percentage } \\
\text { degradation }(\%)\end{array}$ & $\begin{array}{c}\text { Degradation } \\
\text { time }(\mathrm{min})\end{array}$ \\
\hline $\mathrm{ZnO} / \mathrm{TiO}_{2}(2.5 \mathrm{~g})$ & 500 & 97.17 & 30 \\
& 600 & 96.31 & 15 \\
& 700 & 94.81 & 10 \\
& 800 & 95.39 & 15 \\
\hline $\mathrm{ZnO} / \mathrm{TiO}_{2}(5 \mathrm{~g})$ & 500 & 96.63 & 30 \\
& 600 & 95.29 & 15 \\
& 700 & 96.56 & 10 \\
\hline
\end{tabular}


Figure 9 shows the kinetic model photocatalytic degradation of composites $\mathrm{ZnO} / \mathrm{TiO}_{2}$ for $\mathrm{CR}$ solution under light irradiation. Based on the kinetic model, $\mathrm{ZnO} / \mathrm{TiO}_{2}(5 \mathrm{~g})$ at $800^{\circ} \mathrm{C}$ shows the best material for photocatalyst with the highest photocatalytic activity. Figure 9(c) records the photocatalytic performance of CR degradation by using $\mathrm{ZnO} / \mathrm{TiO}_{2}(5 \mathrm{~g})$ at $800^{\circ} \mathrm{C}$ is faster than the other samples.

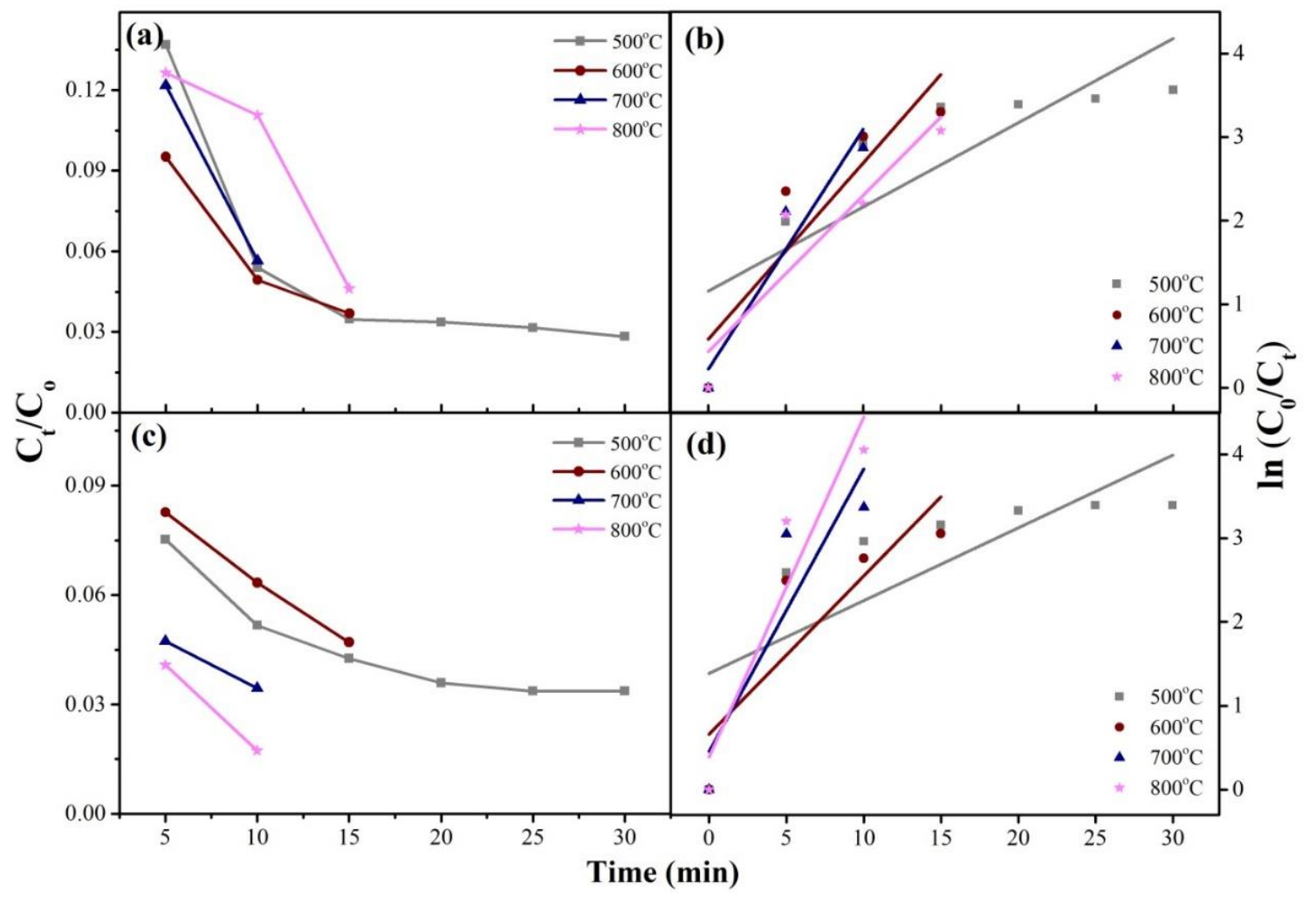

Figure 10. Photocatalytic performance and kinetic model of composites (a-b) $\mathrm{ZnO} / \mathrm{TiO}_{2}$ $(2,5 \mathrm{~g})$ and $(\mathrm{c}-\mathrm{d}) \mathrm{ZnO} / \mathrm{TiO}_{2}(5 \mathrm{~g})$ for various calcination temperature in CR solution

Figure 10(b) and 10(d) shows the photodegradation rate kinetic curves of CR for various calcination temperature of composite materials. The degradation rate constant $\left(\mathrm{k}_{\mathrm{r}}\right)$ in the photocatalytic reaction was calculated by the following equation $[60,64]$ :

$$
\ln \frac{\mathrm{C}_{0}}{\mathrm{C}_{\mathrm{t}}}=\mathrm{k}_{\mathrm{r}} \cdot \mathrm{t}
$$


where $\mathrm{C}_{0}$ is the initial concentration and $\mathrm{C}_{t}$ is the concentration at the time $\mathrm{t}$ and corresponding results for $\mathrm{k}_{\mathrm{r}}$ and $\mathrm{R}^{2}$ for composite $\mathrm{ZnO} / \mathrm{TiO}_{2}$ are shown in Table 4. The $\mathrm{k}_{\mathrm{r}}$ and $\mathrm{R}^{2}$ were increased with increasing the calcination temperature for $\mathrm{ZnO} / \mathrm{TiO}_{2}(5 \mathrm{~g})$ compared to $\mathrm{ZnO} / \mathrm{TiO}_{2}(2.5 \mathrm{~g})$ and the highest rate constant is for composite $\mathrm{ZnO} / \mathrm{TiO}_{2}$ $(5 \mathrm{~g})$ at $800^{\circ} \mathrm{C}$ which faster degradation only for $10 \mathrm{~min}$ irradiation.

Table 4. Rate constants $\left(k_{r}\right)$, correlation coefficient values $\left(R^{2}\right)$, and band gap of $\mathrm{ZnO} / \mathrm{TiO}_{2}$ composites synthesized from Calopogonium mucunoides leaves

\begin{tabular}{ccccc}
\hline Sample & Temperature $\left({ }^{\circ} \mathrm{C}\right)$ & $\mathrm{k}_{\mathrm{r}}\left(\mathrm{min}^{-1}\right)$ & $\mathrm{R}^{2}$ & Band gap (eV) \\
\hline & 500 & 0.11883 & 0.64629 & 3.08 \\
$\mathrm{ZnO} / \mathrm{TiO}_{2}(2.5 \mathrm{~g})$ & 600 & 0.21997 & 0.74324 & 3.11 \\
& 700 & 0.28380 & 0.86531 & 2.89 \\
& 800 & 0.20506 & 0.78970 & 3.02 \\
\hline $\mathrm{ZnO} / \mathrm{TiO}_{2}(5 \mathrm{~g})$ & 500 & 0.11305 & 0.50827 & 3.05 \\
& 600 & 0.20374 & 0.62944 & 3.05 \\
& 700 & 0.33696 & 0.64080 & 3.05 \\
& 800 & 0.40521 & 0.79886 & 3.07 \\
\hline
\end{tabular}

\section{Photocatalytic activity}

The degradation of wastewater in the photocatalytic process by demineralization of pollutant targets with final molecules are $\mathrm{CO}_{2}, \mathrm{H}_{2} \mathrm{O}$, and $\mathrm{N}_{2}$ [29]. During irradiation processes, there is interaction between photon with the charge particle in composite $\mathrm{ZnO} / \mathrm{TiO}_{2}$ at the valence band and produce electron which having energy for moving by excitation to the conduction band and remaining hole in the valence band. The heterojunction band offset link between $\mathrm{ZnO}$ and $\mathrm{TiO}_{2}$ used for transfer electrons from conduction band of $\mathrm{ZnO}$ to conduction band of $\mathrm{TiO}_{2}$ and transfer holes from the valence 
band of $\mathrm{TiO}_{2}$ to the valence band of $\mathrm{ZnO}$ [1]. By this process, the number of electrons in the conduction band of $\mathrm{TiO}_{2}$ and the number of holes in the valence band of $\mathrm{ZnO}$ are increased and suppressing the recombination process. The lifetime of carrier also increases which consequently the degradation process is faster [1,29]. The schematic of degradation process of $\mathrm{CR}$ from the incoming photon, transfer charge (electron and hole) to the final product as shown in Figure 11 for composite $\mathrm{ZnO} / \mathrm{TiO}_{2}$.

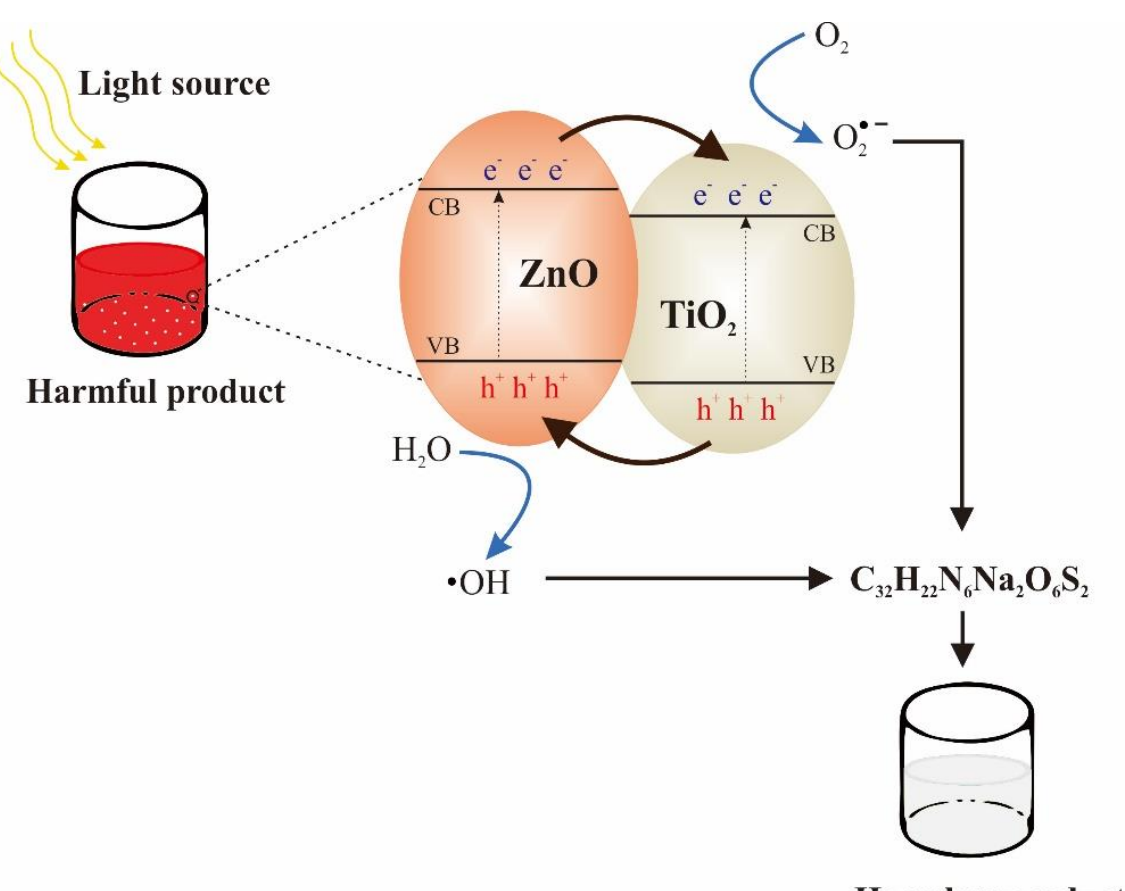

Harmless product

Figure 11. Schematic degradation process of CR from the incoming photon, transfer charge (electron and hole), produce radicals to break the bond of $\mathrm{CR}$, and the final product of photocatalytic in the composite $\mathrm{ZnO} / \mathrm{TiO}_{2}$

Enhancement of electron density in conduction band of $\mathrm{TiO}_{2}$ interacts with the surface of oxygen and it will increase superoxide radicals as products. Hole in valence band reacted with $\mathrm{H}_{2} \mathrm{O}$ that absorbed in surface of semiconductor and the result of the reaction were hydroxyl radicals $(\cdot \mathrm{OH})$. Species of radical active such as $\cdot \mathrm{OH}$ and $\cdot \mathrm{O}_{2}{ }^{-}$ 
were used to mineralize the organic and inorganic contaminants in wastewater $[1,21]$.

Figure 12 shows the active radicals degraded CR dye start by the breaking the bond of molecules $\mathrm{CR}$ and continue with intermediates reaction to mineralize into carbon dioxide, hydrogen dioxide (water), ammonium, and nitrate ion [76].

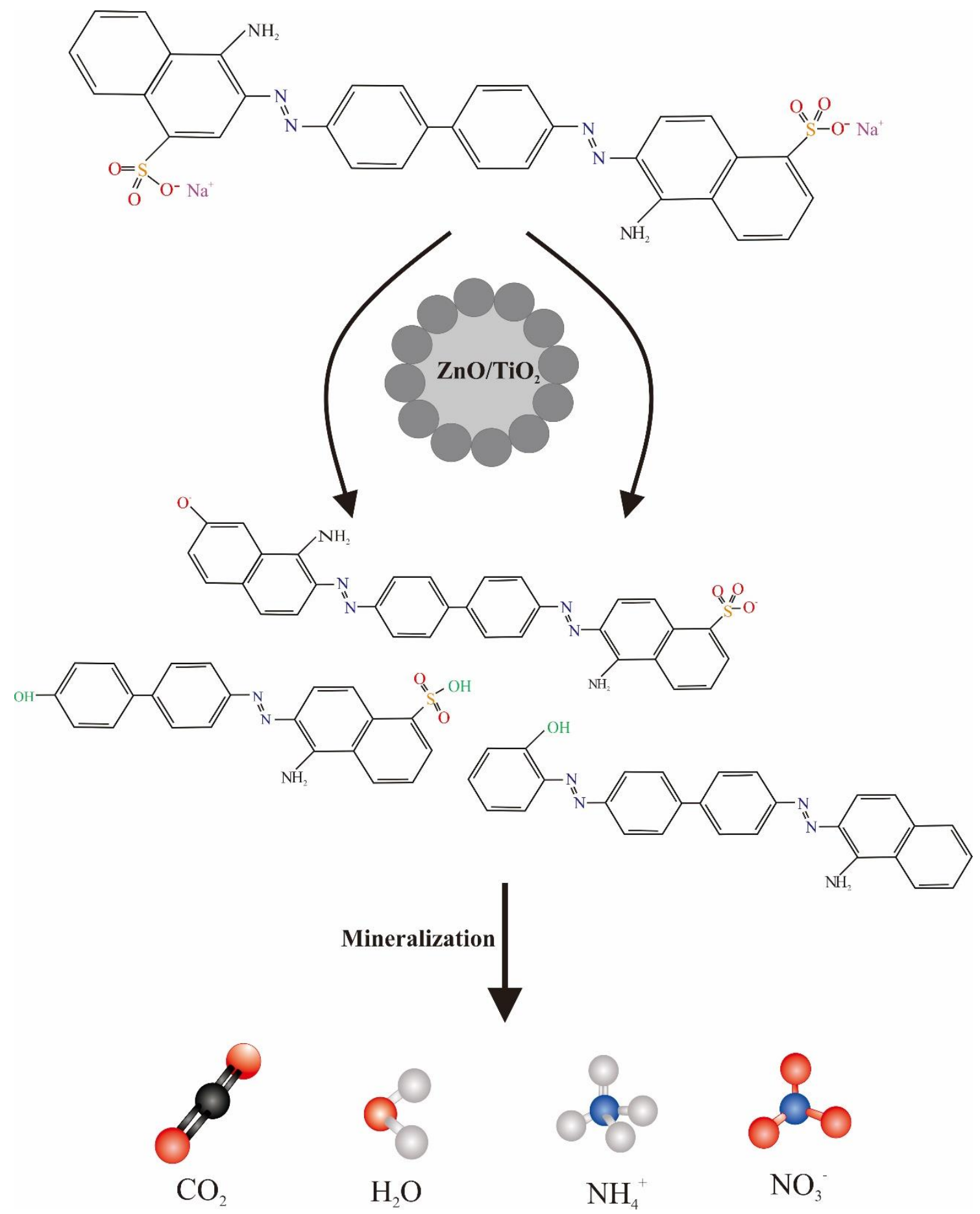


Figure 12. Demineralization mechanism of $\mathrm{CR}$ by the composite $\mathrm{ZnO} / \mathrm{TiO}_{2}$ in the photodegradation process

\section{Recycle}

In this work, five cycles successfully show the ability of composite $\mathrm{ZnO} / \mathrm{TiO}_{2}$ as a new and high potentials photocatalyst to be holistically integrates with environmentally friendly principles and circular chemistry, minimizing wastewater and efficiency of use the energy, water, and chemicals. Figure 13 shows the excellent performance $>95.02 \%$ degradation of CR dye with high stability up to 5 times for every 15 min irradiation.

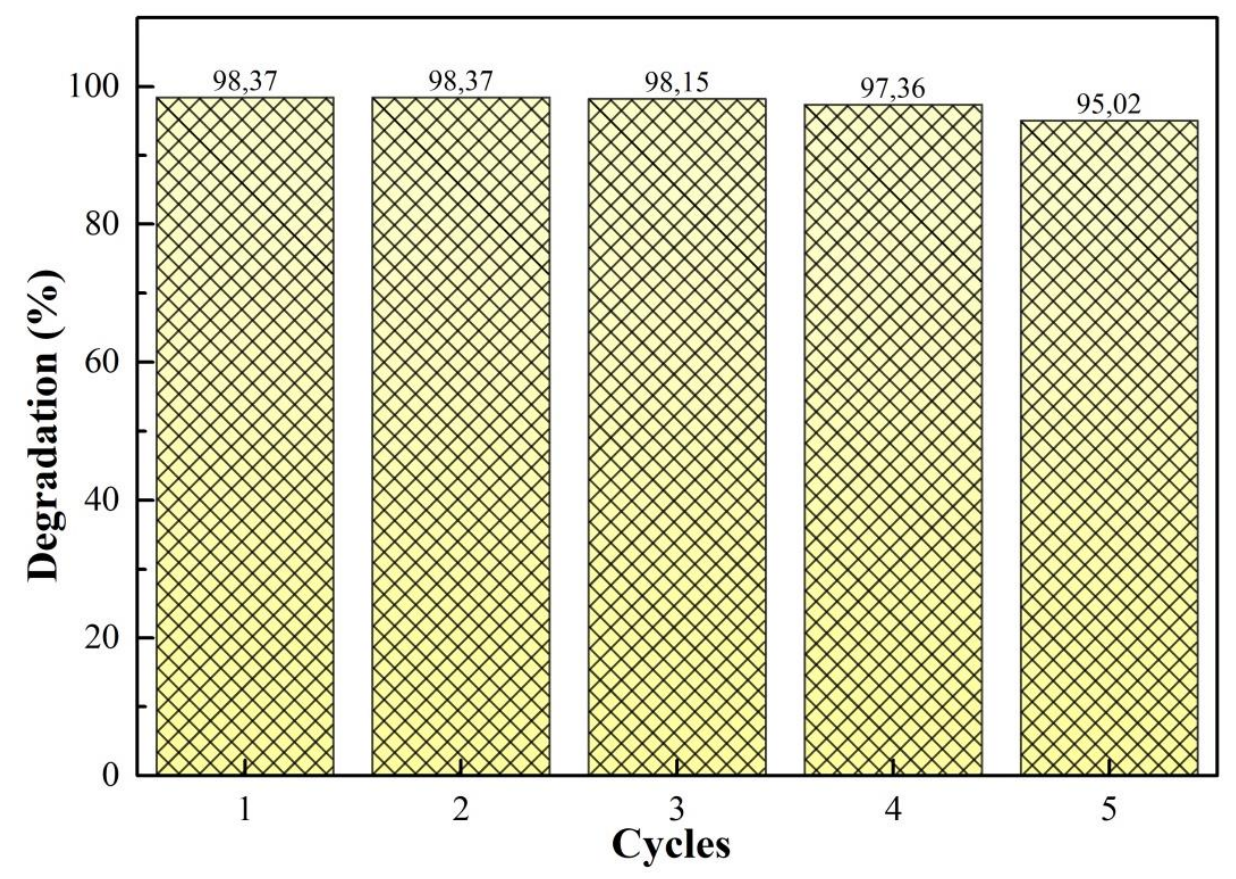

Figure 13. Stability degradation performance of composite $\mathrm{ZnO} / \mathrm{TiO}_{2}$ for $\mathrm{CR}$ dye up to five times

To show the novelty in this study, we have compared the performance of green synthesized composite $\mathrm{ZnO} / \mathrm{TiO}_{2}$ in this study with the previous reported references as shown in Table 5. The treatment time and the degradation performance in this study 
shows high potentially with faster and high stability. It's indicated that the high applicability for the concept holistically integrates with environmentally friendly principles and stability for circular chemistry, minimizing wastewater and efficiency of use the energy and chemicals. 
Table 5. Comparison in this study with previous reported reference of composite $\mathrm{ZnO} / \mathrm{TiO}_{2}$ for various synthesized methods, dye type, light sources, treatment time, and degradation performance. Clearly in this study shows faster (10 min up to30 min) with high stability (5 cycle).

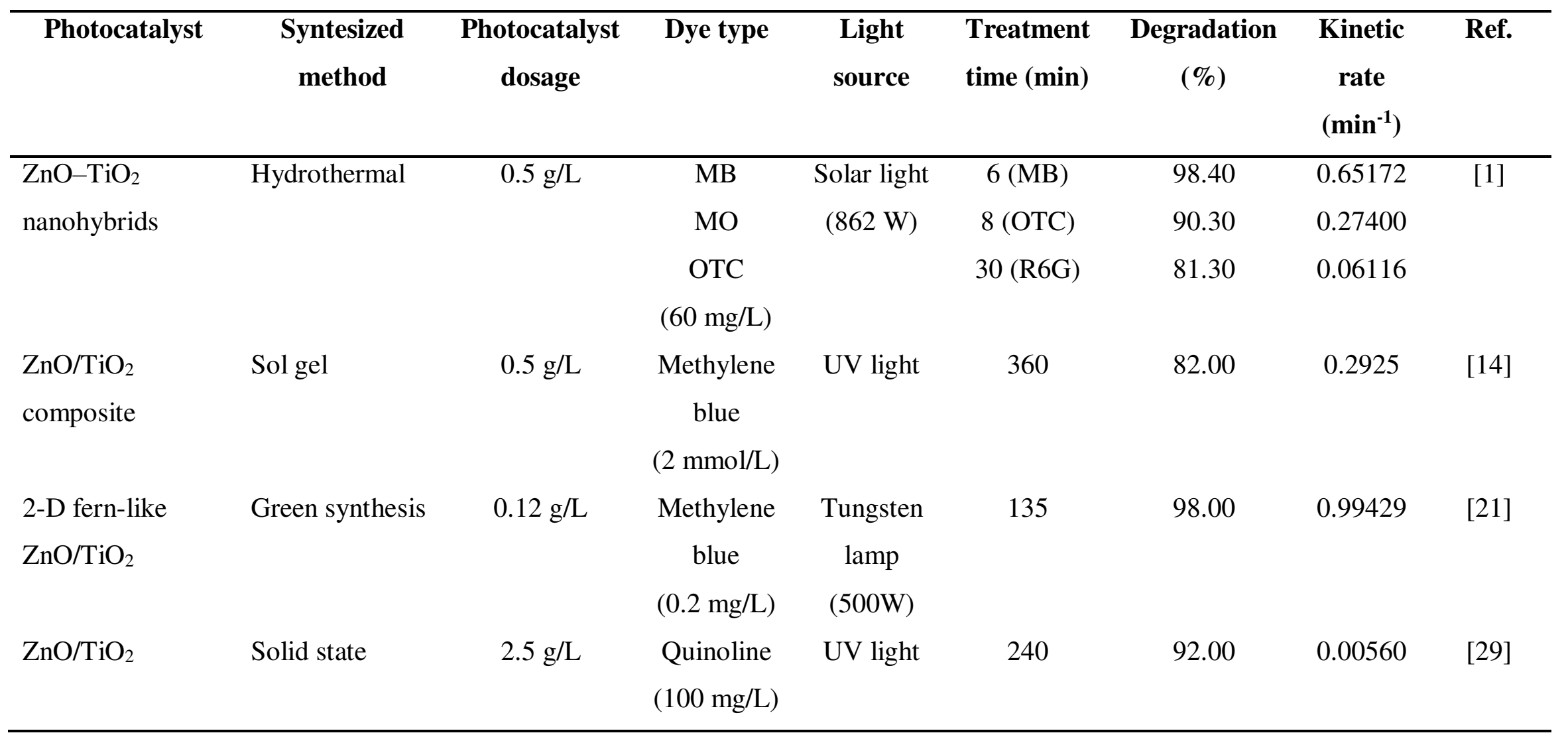




\begin{tabular}{|c|c|c|c|c|c|c|c|c|}
\hline $\begin{array}{l}\mathrm{TiO}_{2} / \mathrm{ZnO} \\
\text { composite sphere }\end{array}$ & Solvothermal & $0.2 \mathrm{~g} / \mathrm{L}$ & $\begin{array}{c}\text { Rhodamine } \\
\text { B } \\
(20 \mu \mathrm{mol} / \mathrm{L})\end{array}$ & $\begin{array}{c}\text { Xenon } \\
\text { lamp } \\
(300 \mathrm{~W})\end{array}$ & 80 & Not available & 0.01400 & [32] \\
\hline $\begin{array}{l}\mathrm{ZnO} / \mathrm{TiO}_{2} \\
\text { nanocomposite }\end{array}$ & $\begin{array}{l}\text { Pulsed laser } \\
\text { ablation }\end{array}$ & $0.5 \mathrm{~g} / \mathrm{L}$ & $\begin{array}{l}\text { Methyl } \\
\text { orange }\end{array}$ & $\begin{array}{c}\text { Xenon } \\
\text { lamp } \\
(500 \mathrm{~W})\end{array}$ & 60 & 98.00 & 0.11420 & [56] \\
\hline $\begin{array}{l}\mathrm{ZnO} / \mathrm{TiO}_{2} \\
\text { nanocomposite }\end{array}$ & $\begin{array}{l}\text { Chemical } \\
\text { method }\end{array}$ & $0.5 \mathrm{~g} / \mathrm{L}$ & $\begin{array}{l}\text { Bentazon } \\
(20 \mathrm{mg} / \mathrm{L})\end{array}$ & UV light & 120 & 84.20 & 0.01540 & [62] \\
\hline $\begin{array}{l}\mathrm{ZnO} / \mathrm{TiO}_{2} \text { thin } \\
\text { film }\end{array}$ & $\begin{array}{l}\text { DC reactive } \\
\text { magnetron } \\
\text { sputtering } \\
\text { technique }\end{array}$ & Thin film & $\begin{array}{c}\text { Methyl } \\
\text { orange } \\
\text { (10 mg/L) }\end{array}$ & UV light & 150 & 91.00 & $\begin{array}{c}\text { Not } \\
\text { available }\end{array}$ & [77] \\
\hline $\begin{array}{l}\mathrm{ZnO} / \mathrm{TiO}_{2} \\
\text { heterojunction }\end{array}$ & $\begin{array}{l}\text { Mechanical } \\
\text { mixing }\end{array}$ & $0.5 \mathrm{~g} / \mathrm{L}$ & $\begin{array}{l}\text { Rhodamine } \\
\text { B } \\
(80 \mathrm{mg} / \mathrm{L})\end{array}$ & $\begin{array}{c}\text { Mercury } \\
\text { lamp } \\
\text { (UV light) }\end{array}$ & 30 & $\sim 45.00$ & $\begin{array}{c}\text { Not } \\
\text { available }\end{array}$ & [78] \\
\hline $\begin{array}{l}\mathrm{ZnO} / \mathrm{TiO}_{2} \\
\text { composite }\end{array}$ & Hydrothermal & Not available & $\begin{array}{c}\mathrm{MB} \\
\mathrm{MO} \\
(0.02 \mathrm{mM})\end{array}$ & Sun light & $\begin{array}{l}60(\mathrm{MB}) \\
60(\mathrm{MO})\end{array}$ & Not available & $\begin{array}{l}0.06100 \\
0.04700\end{array}$ & [79] \\
\hline
\end{tabular}




\begin{tabular}{|c|c|c|c|c|c|c|c|c|}
\hline $\mathrm{ZnO} / \mathrm{TiO}_{2}$ & $\begin{array}{l}\text { Sol gel and } \\
\text { precipitation }\end{array}$ & $0.5 \mathrm{~g} / \mathrm{L}$ & $\begin{array}{c}\text { Methyl } \\
\text { orange } \\
\left(10^{-5} \mathrm{~mol} / \mathrm{L}\right)\end{array}$ & $\begin{array}{l}\text { UV light } \\
(40 \mathrm{~W})\end{array}$ & 360 & 99.5 & 0.01760 & {$[80]$} \\
\hline $\begin{array}{l}\mathrm{ZnO} / \mathrm{TiO}_{2} \\
\text { core/shell }\end{array}$ & $\begin{array}{l}\text { Sol gel } \\
\text { deposition }\end{array}$ & Thin film & $\begin{array}{l}\text { Methylene } \\
\text { blue } \\
(10 \mathrm{mM})\end{array}$ & $\begin{array}{c}\text { LED } \\
(140 \mathrm{~mW}, \\
\text { monochro } \\
\text { matic light } \\
\text { of } 400 \\
\mathrm{~nm})\end{array}$ & 160 & Not available & 0.00700 & {$[81]$} \\
\hline $\begin{array}{l}\mathrm{ZnO} / \mathrm{TiO}_{2} \\
\text { nanocomposite }\end{array}$ & Hydrothermal & $\begin{array}{c}\text { A piece of } \\
\text { composite on } \\
\text { Ti fabric } \\
(1 \mathrm{~cm} \times 1 \mathrm{~cm}) / \\
100 \mathrm{~mL}\end{array}$ & $\begin{array}{c}\text { Methyl } \\
\text { orange } \\
(20 \mathrm{mg} / \mathrm{L})\end{array}$ & $\begin{array}{l}\text { Xe lamp } \\
(300 \mathrm{~W})\end{array}$ & 210 & $\sim 100$ & $\begin{array}{c}\text { Not } \\
\text { available }\end{array}$ & {$[82]$} \\
\hline $\mathrm{ZnO} / \mathrm{TiO}_{2}$ & $\begin{array}{l}\text { Electrostatically } \\
\text { modified } \\
\text { electrospinning }\end{array}$ & $0.6 \mathrm{~g} / \mathrm{L}$ & $\begin{array}{l}\text { Methyl } \\
\text { orange } \\
\text { (3 mg/L) }\end{array}$ & UV light & 360 & Not available & 0.01270 & [83] \\
\hline $\mathrm{ZnO} / \mathrm{TiO}_{2}(2.5 \mathrm{~g})$ & & & & & & & & \\
\hline
\end{tabular}




\begin{tabular}{|c|c|c|c|c|c|c|c|c|}
\hline $500^{\circ} \mathrm{C}$ & Green synthesis & $0.2 \mathrm{~g} / \mathrm{L}$ & $\begin{array}{l}\text { Congo red } \\
(40 \mathrm{mg} / \mathrm{L})\end{array}$ & $\begin{array}{c}\text { Tungsten } \\
\text { lamp } \\
(300 \mathrm{~W})\end{array}$ & 30 & 97.17 & 0.11883 & Present \\
\hline $600^{\circ} \mathrm{C}$ & Green synthesis & $0.2 \mathrm{~g} / \mathrm{L}$ & $\begin{array}{l}\text { Congo red } \\
(40 \mathrm{mg} / \mathrm{L})\end{array}$ & $\begin{array}{c}\text { Tungsten } \\
\text { lamp } \\
(300 \mathrm{~W})\end{array}$ & 15 & 96.31 & 0.21997 & Present \\
\hline $700^{\circ} \mathrm{C}$ & Green synthesis & $0.2 \mathrm{~g} / \mathrm{L}$ & $\begin{array}{l}\text { Congo red } \\
(40 \mathrm{mg} / \mathrm{L})\end{array}$ & $\begin{array}{c}\text { Tungsten } \\
\text { lamp } \\
(300 \mathrm{~W})\end{array}$ & 10 & 94.81 & 0.28380 & Present \\
\hline $800^{\circ} \mathrm{C}$ & Green synthesis & $0.2 \mathrm{~g} / \mathrm{L}$ & $\begin{array}{l}\text { Congo red } \\
(40 \mathrm{mg} / \mathrm{L})\end{array}$ & $\begin{array}{c}\text { Tungsten } \\
\text { lamp } \\
(300 \mathrm{~W})\end{array}$ & 15 & 95.39 & 0.20506 & Present \\
\hline \multicolumn{9}{|c|}{$\mathrm{ZnO} / \mathrm{TiO}_{2}(5 \mathrm{~g})$} \\
\hline $500^{\circ} \mathrm{C}$ & Green synthesis & $0.2 \mathrm{~g} / \mathrm{L}$ & $\begin{array}{l}\text { Congo red } \\
(40 \mathrm{mg} / \mathrm{L})\end{array}$ & $\begin{array}{c}\text { Tungsten } \\
\text { lamp } \\
(300 \mathrm{~W})\end{array}$ & 30 & 96.63 & 0.50827 & Present \\
\hline $600^{\circ} \mathrm{C}$ & Green synthesis & $0.2 \mathrm{~g} / \mathrm{L}$ & $\begin{array}{l}\text { Congo red } \\
(40 \mathrm{mg} / \mathrm{L})\end{array}$ & $\begin{array}{c}\text { Tungsten } \\
\text { lamp } \\
(300 \mathrm{~W})\end{array}$ & 15 & 95.29 & 0.62944 & Present \\
\hline
\end{tabular}




\begin{tabular}{|c|c|c|c|c|c|c|c|c|}
\hline $700^{\circ} \mathrm{C}$ & Green synthesis & $0.2 \mathrm{~g} / \mathrm{L}$ & $\begin{array}{l}\text { Congo red } \\
(40 \mathrm{mg} / \mathrm{L})\end{array}$ & $\begin{array}{c}\text { Tungsten } \\
\text { lamp } \\
(300 \mathrm{~W})\end{array}$ & 10 & 96.56 & 0.64080 & Present \\
\hline $800^{\circ} \mathrm{C}$ & Green synthesis & $0.2 \mathrm{~g} / \mathrm{L}$ & $\begin{array}{l}\text { Congo red } \\
(40 \mathrm{mg} / \mathrm{L})\end{array}$ & $\begin{array}{c}\text { Tungsten } \\
\text { lamp } \\
(300 \mathrm{~W})\end{array}$ & 10 & 98.26 & 0.79886 & Present \\
\hline
\end{tabular}





\section{Conclusion}

The composite $\mathrm{ZnO} / \mathrm{TiO}_{2}$ was synthesized from Calopogonium mucunoides leaf extract by using green synthesis method. The composites were prepared for various calcination temperature $\left(500^{\circ} \mathrm{C}, 600^{\circ} \mathrm{C}, 700^{\circ} \mathrm{C}\right.$, and $\left.800^{\circ} \mathrm{C}\right)$ and different concentration of $\mathrm{TiO}_{2}(2.5 \mathrm{~g}$ and $5 \mathrm{~g})$. From XRD analysis, the crystallite size of composites was influenced by the concentration of $\mathrm{TiO}_{2}$ and calcination temperature during the synthesis. FTIR spectra observed the $\mathrm{Zn}-\mathrm{O}$ band at the peak $446 \mathrm{~cm}^{-1}$ and $\mathrm{O}-\mathrm{Ti}-\mathrm{O}$ band at the peak $723 \mathrm{~cm}^{-1}$. The optical properties were analyzed by using $\mathrm{K}-\mathrm{K}$ relation from the infra-red spectra, it shows the highest energy loss function and distance between optical phonon vibration modes $(\Delta \mathrm{LO}-\mathrm{TO})$ is in the $\mathrm{ZnO} / \mathrm{TiO}_{2}(5 \mathrm{~g})$ at temperature $800^{\circ} \mathrm{C}$. It indicates the stable and strong bonding formation and the lattice match in the composite which has effect to enhance photocatalytic activity. According to UV-Vis study, the synthesis of $\mathrm{ZnO} / \mathrm{TiO}_{2}$ shows high effectivity in photodegradation of $\mathrm{CR}$ dye. The materials presented the excellent photocatalytic performance with highest degradation efficiency for composite $\mathrm{ZnO} / \mathrm{TiO}_{2}(5 \mathrm{~g})$ at $800^{\circ} \mathrm{C}$. In this study shows high potentially with faster and high stability, indicated that high applicability concept for holistically integrates with environmentally friendly principles and high stability for circular chemistry, and efficiency of use the energy and chemicals.

\section{Acknowledge}

This work was supported by the PT (Penelitian Terapan) funded by the Indonesia Government (Kemenristek/BRIN) grants 2021.

\section{References}


[1] J. Singh, S. Kumar, Rishikesh, A.K. Manna, R.K. Soni, Fabrication of $\mathrm{ZnO}-\mathrm{TiO}_{2}$ nanohybrids for rapid sunlight driven photodegradation of textile dyes and antibiotic residue molecules, Opt. Mater. $107 \quad$ (2020) 110138. https://doi.org/10.1016/j.optmat.2020.110138.

[2] C.A.S. Robles, P. A. Luque, C. M. G. Gutiérrez, O. Nava, A.R.V. Nestor, E.L. Medina, R. Ranjithkumar, A.C. Beltrán, Study on the effect of the concentration of Hibiscus sabdariffa extract on the green synthesis of $\mathrm{ZnO}$ nanoparticles, Results in Phys. 15 (2019) 102807. https://doi.org/10.1016/j.rinp.2019.102807.

[3] S.M.T.H. Moghaddas, B. Elahi, V. Javanbakht, Biosynthesis of pure zinc oxide nanoparticles using Quince seed mucilage for photocatalytic dye degradation, J. Alloys Compd. 821 (2020) 153519. https://doi.org/10.1016/j.jallcom.2019.153519.

[4] M.M. Ghoneim, H.S. El-Desoky, N.M. Zidan, Electro-Fenton oxidation of sunset yellow FCF azo-dye in aqueous solutions, Desalination 274 (1-3) (2011) 22-30. https://doi.org/10.1016/j.desal.2011.01.062.

[5] M.B. Shekardasht, M.H. Givianrad, P.Gharbani, Z. Mirjafary, A. Mehrizad, Preparation of a novel Z-scheme $\mathrm{g}-\mathrm{C}_{3} \mathrm{~N}_{4} / \mathrm{RGO} / \mathrm{Bi}_{2} \mathrm{Fe}_{4} \mathrm{O}_{9}$ nanophotocatalyst for degradation of congo red dye under visible light, Diamond \& Related Mater. 109 (2020) 108008. https://doi.org/10.1016/j.diamond.2020.108008.

[6] X. Wang, B. Deng, L. Yu, E. Cui, Z. Xiang, W. Lu, Degradation of azo dyes congo red by MnBi alloy powders: performance, kinetics and mechanism, Mater. $\begin{array}{llll}\text { Chem. } & \text { Phys. } & 251 & \text { (2020) }\end{array}$ https://doi.org/10.1016/j.matchemphys.2020.123096. 
[7] M.M. Tauber, G.M. Gübitz, A.Rehorek, Degradation of azo dye by oxidation processes-laccase and ultrasound treatment, Bioresource Technol. 99 (10) (2008) 4213-4220. https://doi.org/10.1016/j.biortech.2007.08.085.

[8] Y.P. Feng, N. Gaztelumendi, J. Fornell, H.Y. Zhang, P. Solsona, M.D. Baro, S. Surinach, E. Ibanez, L. Barrios, E. Pellicer, C. Nogues, J. Sort, Mechanical properties, corrosion performance, and cell viability studies on newly developed porous Fe-Mn-Si-Pd alloy, J. Alloys Compd. 724 (2017) 1046-1056. https://doi.org/10.1016/j.jallcom.2017.07.112.

[9] S.A. Bhat, F. Zafar, A.H. Mondal, A. Kareem, A.U. Mirza, S. Khan, A. Mohammad, Q.M.R. Haq, N. Nishat, Photocatalytic degradation of carcinogenic congo red dye in aqueous solution, antioxidant activity and bactericidal effect of $\mathrm{NiO}$ nanoparticles, J. Iran. Chem. Soc. 17 (1) (2020) 215-227. https://doi.org/10.1007/s13738-019-01767-3.

[10] A.R. Binupriya, M. Sathishkumar, K. Swaminathan, C.S. Kuz, S.E. Yun, Comparative studies on removal of congo red by native and modified mycelial pellets of trametes versicolor in various reactor modes, Bioresource Technol. 99 (5) (2008) 1080-1088. https://doi.org/10.1016/j.biortech.2007.02.022.

[11] D. Tekin, H. Kiziltas, H. Ungan, Kinetic evaluation of $\mathrm{ZnO} / \mathrm{TiO}_{2}$ thin film photocatalyst in photocatalytic degradation of Orange G, J. Molec. Liquids 306 (2020) 112905. https://doi.org/10.1016/j.molliq.2020.112905.

[12] M. Kazemaini, M. Nikkhah, M. Fattahi, L. Vafajoo, Physiochemical properties and catalytic performances of nanostructured $\mathrm{V}_{2} \mathrm{O}_{5}$ over $\mathrm{TiO}_{2}$ and $\gamma-\mathrm{Al}_{2} \mathrm{O}_{3}$ for oxidative dehydrogenation of propane, Chem. Biochem. Eng. Q. 30 (2016) 9-18. https://doi.org/10.15255/CABEQ.2014.2049. 
[13] A.H. Zyoud, A. Zubi, S. Hejjawi, S.H. Zyoud, M.H. Helal, S.H. Zyoud, N. Qamhiehe, A.R. Hajamohideen, H.S. Hilal, Removal of acetaminophen from water by simulated solar light photodegradation with $\mathrm{ZnO}$ and $\mathrm{TiO} 2$ nanoparticles: Catalytic efficiency assessment for future prospects, J. Environ. Chem. Eng. 8 (2020) 104038. https://doi.org/10.1016/j.jece.2020.104038.

[14] L. Munguti, F. Dejene, Influence of annealing temperature on structural, optical, and photocatalytic properties of $\mathrm{ZnO}-\mathrm{TiO}_{2}$ composites for application in dye removal in water, Nano-Struct. Nano-Objects $24 \quad$ (2020) 100594. https://doi.org/10.1016/j.nanoso.2020.100594.

[15] K.M. Lee, C.W. Lai, K.S. Ngai, J.C. Juan, Recent development of zinc oxide based photocatalyst in water treatment technology: A review, Water Res. 88 (2016) 428-448. https://doi.org/10.1016/j.watres.2015.09.045.

[16] G. Madhumitha, J. Fowsiya, N. Gupta, A. Kumar, M. Singh, Green synthesis, characterization and antifungal and photocatalytic activity of Pithecellobium dulce peel mediated ZnO nanoparticles, J. Phys. Chem. Solids 127 (2019) 43-51. https://doi.org/10.1016/j.jpcs.2018.12.005.

[17] N.T. Hanh, N.L.M. Tri, D.V. Thuan, M.H.T. Tung, T.D. Pham, T.D. Minh, H.T. Trang, M.T. Binh, M.V. Nguyen, Monocrotophos pesticide effectively removed by novel visible light driven $\mathrm{Cu}$ doped $\mathrm{ZnO}$ photocatalyst, J. Photochem. $\begin{array}{lllll}\text { Photobiol. } & \text { A.: } & \text { Chem. } & 382 & \text { (2019) }\end{array}$ https://doi.org/10.1016/j.jphotochem.2019.111923.

[18] H. Bouzid, M. Faisal, F.A. Harraz, S.A. AL-Sayari, A.A. Ismail, Synthesis of mesoporous $\mathrm{Ag} / \mathrm{ZnO}$ catalyst and photocatalyst activity, Catal. Today 252 (2015) 20-26. https://doi.org/10.1016/j.cattod.2014.10.011. 
[19] N.T. Truc, D.T. Tran, N.T. Hanh, T.D. Pham, Novel visible light-driven NbDoped $\mathrm{Ta}_{3} \mathrm{~N}_{5}$ sensitized/protected by PPy for efficient overall water splitting, Int. J. Hydrogen $\quad 43 \quad$ Energy $\quad 42018) \quad$ 5480-5495. https://doi.org/10.1016/j.ijhydene.2018.06.128.

[20] M.R.D. Khaki, M.S. Shafeeyan, A.A.A. Raman, W.M.A W. Daud, Enhanced UVVisible photocatalytic activity of $\mathrm{Cu}$-doped $\mathrm{ZnO} / \mathrm{TiO}_{2}$ nanoparticles, J. Mater. Sci. Mater. Electron. 29 (2018) 5480-5495. https://doi.org/10.1007/s10854-017-85159.

[21] N. Suganthi, S. Thangavel, K. Kannan, Hibiscus subdariffa leaf extract mediated 2-D fern-like $\mathrm{ZnO} / \mathrm{TiO} 2$ hierarchical nanoleaf for photocatalytic degradation, FlatChem 24 (2020) 100197. https://doi.org/10.1016/j.flatc.2020.100197.

[22] M.S.H. Bhuiyan, M.Y. Miah, S.C. Paul, T.D. Aka, O. Saha, M.M. Rahaman, M.J.I. Sharif, O. Habiba, M. Ashaduzzaman, Green synthesis of iron oxide nanoparticle using Carica papaya leaf extract: application for photocatalytic degradation of remazol yellow RR dye and antibacterial activity, Heliyon 6 (2020) e04603. https://doi.org/10.1016/j.heliyon.2020.e04603.

[23] H. Kamani, S. Nasseri, M. Khoobi, R.N. Nodehi, A.H. Mahvi, Sonocatalytic degradation of humic acid by $\mathrm{N}$-doped $\mathrm{TiO}_{2}$ nano-particle in aqueous solution, J.Environ. Health Sci. Eng. 14 (2016) 3. https://doi.org/10.1186/s40201-0160242-2.

[24] R. Ashouri, P. Ghasemipoor, B. Rasekh, F. Yazdin, S. Mofradnia, The effect of $\mathrm{ZnO}$-based carbonaceous materials for degradation of benzoic pollutants: a review, $\begin{array}{llllll}\text { Int. J. } & \text { Environ. } & \text { Sci. } & \text { Technol. } & 16 & \text { (2019) }\end{array}$ https://doi.org/10.1007/s13762-018-2056-5. 
[25] M.H. Malakooti, H.S. Hwang, H.A. Sodano, Morphology-controlled ZnO nanowire array for tailored hybrid composites with high damping, ACS Appl. Mater. Interfaces 7 (2014) 332-339. https://doi.org/10.1021/am506272c.

[26] H. Fang, Y. Guo, T. Wu, Y. Liu, Biomimetic synthesis of urchin-like $\mathrm{CuO} / \mathrm{ZnO}$ nanocomposites with excellent photocatalytic activity, New J. Chem. 42 (2018) 12779-12786. https://doi.org/10.1039/C8NJ02052C.

[27] S. Ma, J. Xue, Y. Zhou, Z. Zhang, Photochemical synthesis of $\mathrm{ZnO} / \mathrm{Ag}_{2} \mathrm{O}$ heterostructures with enhanced ultaviolet and visible photocatalytic activity, J. Mater. Chem. A. 2 (2014) 7272-7280. https://doi.org/10.1039/C4TA00464G.

[28] D. Ma, J. W. Shi, Y. Zou, Z. Fan, X. Ji, C. Niu, Highly efficient photocatalyst based on CdS quantum dots/ZnO nanosheets 0D/2D heterojunction for hydrogen evolution from water splitting, ACS Appl. Mater. Interfaces 9 (2017) 2537725386. https://doi.org/10.1021/acsami.7b08407.

[29] D. Gupta, R. Chauhan, N. Kumar, V. Singha, V.C. Srivastava, P. Mohanty, T.K. Mandal, Enhancing photocatalytic degradation of quinoline by $\mathrm{ZnO}: \mathrm{TiO} 2$ mixed oxide: Optimization of operating parameters and mechanistic study, J. Environ. Management 258 (2020) 110032. https://doi.org/10.1016/j.jenvman.2019.110032.

[30] K.S. Stefaríska, A. Kubiak, A. Piasecki, J. Goscianska, G. Nowaczyk, S. Jurga, T. Jesionowski, $\mathrm{TiO}_{2}-\mathrm{ZnO}$ binary oxide systems: comprehensive characterization and tests of photocatalytic activity, Materials $11 \quad(2018) \quad 841$. https://doi.org/10.3390/ma11050841.

[31] C. Cheng, A. Amini, C. Zhu, Z. Xu, H. Song, N. Wang, Enhanced photocatalytic performance of $\mathrm{TiO}_{2}-\mathrm{ZnO}$ hybrid nanostructures, Sci. Rep. 4 (2014) 4181. https://doi.org/10.1038/srep04181. 
[32] L. Pan, G.Q. Shen, J.W. Zhang, X.C. Wei, L.Wang, J.J. Zou, X. Zhang, TiO $2-Z n O$ composite sphere decorated with $\mathrm{ZnO}$ clusters for effective charge isolation in photocatalysis, Indus. Eng. Chem. Res. $54 \quad$ (2015) 7226-7232. https://doi.org/10.1021/acs.iecr.5b01471.

[33] M.Y. Guo, M.K. Fung, F. Fang, X.Y. Chen, A.M.C. Ng, A.B. Djurišić, W.K. Chan, $\mathrm{ZnO}$ and $\mathrm{TiO}_{2}$ 1D nanostructures for photocatalytic applications, J. Alloys Compd. 509 (2011) 1328-1332. https://doi.org/10.1016/j.jallcom.2010.10.028.

[34] M. Hosseini, A. Haghighatzadeh, Bmazinani, Enhanced third-order optical susceptibility in heterogeneous wurtzite $\mathrm{ZnO} /$ anatase $\mathrm{TiO}_{2}$ core/ shell nanostructures via controlled $\mathrm{TiO}_{2}$ shell thickness, Opt. Mater. 92 (2019) 1-10. https://doi.org/10.1016/j.optmat.2019.03.042.

[35] G.K. Upadhyay, J.K. Rajput, T.K. Pathak, V. Kumar, L.P. Purohit, Synthesis of zno:tio 2 nanocomposites for photocatalyst application in visible light, Vacuum 160 (2019) 154-163. https://doi.org/10.1016/j.vacuum.2018.11.026.

[36] F.A.M. Al-Zahrani, R.M. El-Shishtawy, N.S.E. Ahmed, N.S. Awwad, M.S. Hamdy. A.M. Asiri, Photocatalytic decolourization of a new water-insoluble organic dye based on phenothiazine by $\mathrm{ZnO}$ and $\mathrm{TiO}_{2}$ nanoparticles, Arabian $\mathrm{J}$. Chem. 13 (2020) 3633-3638. https://doi.org/10.1016/j.arabjc.2019.12.007.

[37] H. Wang, L. Zhang, L. Chen, J. Hu, S. Li, Z. Wang, J. Liu, X. Wang, Semiconductor heterojunction photocatalysts: design, construction, and photocatalytic performances, Chem. Soc. Rev. 24 (2014) 5234-5244. https://doi.org/10.1039/C4CS00126E.

[38] S. Deebansok, T. Amornsakchai, P. Sae-ear, P. Siriphannon, S. M. Smith, Spherelike and flake-like $\mathrm{ZnO}$ immobilized on pineapple leaf fibers as easy-to-recover 
photocatalyst for the degradation of congo red, J. Environ. Chem. Eng. 9 (2020) 104746. https://doi.org/10.1016/j.jece.2020.104746.

[39] U.O. Bhagwat, J.J. Wu, A.M. Asiri, S. Anandan, Sonochemical Synthesis of Mg$\mathrm{TiO}_{2}$ nanoparticles for persistent congo red dye degradation, J. Photochem. $\begin{array}{lllll}\text { Photobiol. } & \text { A. } & 346 & \text { (2017) }\end{array}$ https://doi.org/10.1016/j.jphotochem.2017.06.043.

[40] P.S. Basavarajappa, S.B. Patil, N. Ganganagappa, K.R. Reddy, A.V. Raghu, C.V. Reddy, Recent progress in metal-doped $\mathrm{TiO}_{2}$, non-nanometal doped/codoped $\mathrm{TiO}_{2}$ and $\mathrm{TiO}_{2}$ nanostructured hybrids for enhanced photocatalysis, International $\mathrm{J}$. Hydrogen $\quad$ Energy $\quad 45 \quad$ (13) $\quad$ (2020) https://doi.org/10.1016/j.ijhydene.2019.07.241.

[41] S. Feizpoor, A.H. Yangjeh, K. Yubuta, Integration of carbon dots and polyaniline with $\mathrm{TiO}_{2}$ nanoparticles: substantially enhanced photocatalytic activity to removal various pollutants under visible light, J. Photochem. Photobiol. A. 367 (2018) 94104. https://doi.org/10.1016/j.jphotochem.2018.08.017.

[42] K.R. Reddy, K.V. Karthik, S.B.B. Prasad, S.K. Soni, H.M. Jeong, A.V. Raghu, Enhanced photocatalytic activity of nanostructured titanium dioxide/polyaniline hybrid photocatalyst, Polyhedron $120 \quad$ (2016) 169-174. https://doi.org/10.1016/j.poly.2016.08.029.

[43] J.F. de Lima, M.H. Harunsani, D.J. Martin, D. Kong, P.W. Dunne, D. Gianolio, R.J. Kashtiban, J. Sloan, O.A. Serra, J. Tang, R.I. Walton, Control of chemical state of cerium in doped anatase $\mathrm{TiO}_{2}$ by solvothermal synthesis and its application in photocatalytic water reduction, J. Mater. Chem. A. 3 (2015) 98909898. https://doi.org/10.1039/C5TA01474C. 
[44] G.S. Guo, C.N. He, Z.H. Wang, F.B. Gu, D.M. Han, Synthesis of titania and titanate nanomaterials and their application in environmental analytical chemistry, Talanta 72 (2007) 1687-1692. https://doi.org/10.1016/j.talanta.2007.03.039.

[45] A.Z.Y. Qu, S. Ali, N. Sun, H. Lu, R. Yan, X. Zhang, L. Jing, Improved visiblelight activities for degrading pollutants on $\mathrm{TiO}_{2} / \mathrm{g}-\mathrm{C}_{3} \mathrm{~N}_{4}$ nanocomposites by decorating SPR Au nanoparticles and 2,4-dichlorophenol decomposition path, J. Hazard. $\quad$ Mater. $\quad 342 \quad$ (2018) https://doi.org/10.1016/j.jhazmat.2017.09.005.

[46] J. Zhou, G. Tian, Y. Chen, J. Wang, X. Cao, Y. Shi, K. Pan, H. Fu, Synthesis of hierarchical $\mathrm{TiO}_{2}$ nanoflower with anatase-rutile heterojunvtion as $\mathrm{Ag}$ support for efficient visible-light photocatalytic activity, Dalton Trans. 42 (2013) 1124211251. https://doi.org/10.1039/C3DT51293B.

[47] C. Vidya, C. Manjunatha, M.N. Chandraprabha, M. Rajshekar, M. A. L. A. Raj, Hazard free green synthesis of $\mathrm{ZnO}$ nano-photo-catalyst using Artocarpus Heterophyllus leaf extract for the degradation of congo red dye in water treatment applications, J. Environ. Chem. Eng. $5 \quad$ (2017) 3172-3180. http://dx.doi.org/10.1016/j.jece.2017.05.058.

[48] S.P. Goutam, G. Saxena, V. Singh, A.K. Yadav, R.N. Bharagava, K.B. Thapa, Green synthesis of $\mathrm{TiO}_{2}$ nanoparticles using leaf extracts of Jatropha curcas L for photocatalytic degradation of tannery wastewater, Chem. Eng. J. 335 (2018) 386396. https://doi.org/10.1016/j.cej.2017.12.029.

[49] P.A. Luquea, O. Navaa, C.A. Soto-Roblesa, M.J. Chinchillas-Chinchillasa, H.E. Garrafa-Galvezb, Y.A. Baez-Lopeza, K.P. Valdez-Núñezc, A.R. Vilchis-Nestord, A. Castro-Beltránb, Improved photocatalytic efficiency of $\mathrm{SnO}_{2}$ nanoparticles 
through green synthesis, Opt. Int. J. Light and Electron Optics 206 (2020) 164299. https://doi.org/10.1016/j.ijleo.2020.164299.

[50] S. Yedurkar, C. Maurya, P. Mahanwar, Biosynthesis of zinc oxide nanoparticles using Coccinea leaf extract -a green approach, Open Journal of Synthesis and Applications 5 (2016) 1-14. http://dx.doi.org/10.4236/ojsta.2016.51001.

[51] D. Wu, C. Li, Q. Kong, S. Zaifeng, D. Zhang, L. Wang, L. Han, X. Zhang, Q. Lin, Photocatalytic activity of $\mathrm{Lu}^{3+/} \mathrm{TiO}_{2}$ prepared by ball milling method, Journal of Rare Earths 8 (36) (2018) 819-825. https://doi.org/10.1016/j.jre.2018.01.016.

[52] S. Ilyas, Heryanto, B. Abdullah, D. Tahir, X-ray diffraction analysis of nanocomposite $\mathrm{Fe}_{3} \mathrm{O}_{4}$ /activated carbon by Williamson-Hall and size-strain plot methods, Nano-Struct. Nano-Objects $\quad 20 \quad$ (2019) 100396. https://doi.org/10.1016/j.nanoso.2019.100396.

[53] B. Abdullah, S. Ilyas, D. Tahir, Nanocomposites Fe/Activated Carbon/PVA for Microwave Absorber: Synthesis and Characterization, J. Nanomater. 2018 (2018) 9823263. https://doi.org/10.1155/2018/9823263.

[54] Heryanto, Hendri, B. Abdullah, D. Tahir, Analysis of structural properties of Xray diffraction for composite copper-activated carbon by modified WilliamsonHall and size-strain plotting methods, J. Phys.: Conf. Ser. 1080 (1) (2018) 012007. https://doi.org/10.1088/1742-6596/1080/1/012007.

[55] I. Choudhary, R. Shukla, A. Sharma, K Raina, Effect of excitation wavelength ang europium doping on the optical properties of nanoscale zinc oxide, J. Mater. Sci.: Mater. Electron. 31 (2020) 20033-20042. https://doi.org/10.1007/s10854020-04525-X. 
[56] M.A. Gondal, A.M. Ilyas, U. Baig, Pulsed laser ablation in iquid synthesis of $\mathrm{ZnO} / \mathrm{TiO}_{2}$ nanocomposite catalyst with enhanced photovoltaic and photocatalytic performance, Ceramic International $42 \quad$ (2016) 13151-13160. https://doi.org/10.1016/j.ceramint.2016.05.104.

[57] M. Jose, M. Elakiya, S.A.M.B. Dhas, Structural and optical properties of nanosized $\mathrm{ZnO} / \mathrm{ZnTiO}_{3}$ composite materials synthesized by a facile hydrothermal technique, J. Mater. Sci.: Mater. Electron. 28 (2017) 13649-13658. https://doi.org/10.1007/s10854-017-7207-9.

[58] Y.C. Liang, C.Y. Hu, Y.C. Liang, Crystallographic phase evolution of ternary ZnTi-O nanomaterials during high temperature annealing of $\mathrm{ZnO}^{-\mathrm{TiO}_{2}}$ nanocomposites, $\quad$ CrystEngComm $\quad 14 \quad$ (2012) 5579-5584. https://doi.org/10.1039/C2CE25347J.

[59] S. Mathur, M. Arya, R. Jain, S.K. Sharma, Effect of annealing temperature on structural, electrical, and optical properties of $\mathrm{TiO}_{2}$ nanopowder, J. Nanostruct. 7 (2) (2017) 121-126. https://dx.doi.org/10.22052/jns.2017.02.005.

[60] S. Ilyas, B. Abdullah, D. Tahir, Enhancement of absorbing frequency and photocatalytic performance by temperature treatment of composites $\mathrm{Fe}_{3} \mathrm{O}_{4}-\mathrm{AC}$ naniparticle, Adv. Powder Technol. $31 \quad$ (2020) 905-913. https://doi.org/10.1016/j.apt.2019.11.007.

[61] B. Ulum, S. Ilyas, A.N. Fahri, I. Mutmainna, M.A. Anugrah, N. Yudasari, E.B. Demmalino, D. Tahir, Composite carbon-lignin/ zinc oxide nanocrystalline ball-like hexagonal mediated from Jatropha curcas L leaf as photocatalyst for industrial dye degradation, J. Inorg. Organomet. Polym. Mater. 30 (12) (2020) 4905-4916. https://doi.org/10.1007/s10904-020-01631-5. 
[62] M. Gholami, M.S. Siboni, M. Farzadkia, J.K. Yang, Synthesis, characterization, and application of $\mathrm{ZnO} / \mathrm{TiO}_{2}$ nanocomposite for photocatalysis of a herbicide (Bentazon), Desalination and Water Treatment 57 (29) (2016) 13632-13644. https://doi.org/10.1080/19443994.2015.1060541.

[63] S. Bagheri, K. Shameli, S.B.A. Hamid, Synthesis and characterization of anatase titanium dioxide nanoparticles using egg white solution via sol-gel method, J. Chem. 2013 (2013) 848205. https://doi.org/10.1155/2013/848205.

[64] N. Rauf, S. Ilyas, H. Heryanto, R. Rahmat, A. N. Fahri, M.H. Rahmi, D. Tahir, The correlation between structural and optical properties of zinc hydroxide nanoparticle in supports photocatalytic performance, Opt. Mater. 112 (2021) 110780. https://doi.org/10.1016/j.optmat.2020.110780.

[65] S. Suryani, H. Heryanto, R. Rusdaeni, A.N. Fahri, D. Tahir, Quantitative analysis of diffraction and infra-red spectra of composite cement $/ \mathrm{BaSO}_{4} / \mathrm{Fe}_{3} \mathrm{O}_{4}$ for determining correlation between attenuation coefficient, structural, and optical properties, Ceramic International $46 \quad$ (2020) 18601-18607. https://doi.org/10.1016/j.ceramint.2020.04.170.

[66] D. Tahir, S.K. Oh, H.J. Kang, S. Tougaard, Quantitative analysis of reflection electron energy loss spectra to determine electronic and optical properties of FeNi alloy thin films, J. Electron. Spectrosc. Relat. Phenom. 206 (2016) 6-11. https://doi.org/10.1016/j.elspec.2015.11.005.

[67] D. Tahir, S. Tougaard, Electronic and optical properties of selected polymers studied by reflection electron energy loss spectroscopy, J. Appl. Phys. 111 (2012) 054101. https://doi.org/10.1063/1.3688327. 
[68] G.H. Khorrami, A.K. Zak, A. Kompany, R. Yousefi, Optical and Structural properties of $\mathrm{X}$-doped (X=Mn, Mg, and Zn) PZT nanoparticle by Kramers-Kronig and size strain plot methods, Ceramic International 38 (2002) 5683-5690. https://doi.org/10.1016/j.ceramint.2012.04.012.

[69] Y. Yang, S. He, Y. Ye, X. Cao, H. Liu, Z. Wu, J. Yue, H. Sue, Enhanced hydrophobicity of soybean protein isolate by low-pH shifting treatment fot the sub-micron gel particles praparation, Ind. Crop. Prod. 151 (2020) 113709. https://doi.org/10.1016/j.indcrop.2020.112475.

[70] M. Ghasemifard, E. Fathi, M. Ghamari, The effect of $\mathrm{Fe}^{3+}$-doped on structure and optical properties of mesoporous $\mathrm{Al}_{2} \mathrm{O}_{3} / \mathrm{SiO}_{2}$ composite, Mater. Sci. Semicond. Process. 42 (2016) 349-353. https://doi.org/10.1016/j.mssp.2015.11.001.

[71] X. Lu, J. Chen, M. Zheng, J. Guo, J. Qi, Y. Chen, S. Miao, B. Zheng, Effect of highintensity ultrasound irradiation on the stability and structural features of coconutgrain milk composite system utilizing maize kernels and starch with different amylose contents, Ultrason. Sonochem. 55 (2019) 135-148. https://doi.org/10.1016/j.ultsonch.2019.03.003.

[72] D. Tahir, S.K. Oh, H.J. Kang, S. Tougaard, Composition dependence of dielectric and optical properties of Hf-Zr-silicate thin films grown on Si (100) by atomic layer deposition, Thin Solid Films $116 \quad$ (2016) 425-430. https://doi.org/10.1016/j.tsf.2016.09.001.

[73] D. Tahir, Suarga, N.H. Sari, Yulianti, Stopping powers and inelastic mean free path of $200 \mathrm{eV}-50 \mathrm{keV}$ electrons in polymer PMMA, PE, and PVC, Applied $\begin{array}{llll}\text { Radiation } \quad \text { and } \quad \text { Isotopes } & 95 \quad \text { (2015) }\end{array}$ https://doi.org/10.1016/j.apradiso.2014.10.001. 
[74] S. Mugundan, B. Rajamman, G. Viruthagiri, N. Shanmugam, R. Gobi, P. Praveen, Synthesis and characterization of undope and cobalt-doped $\mathrm{TiO}_{2}$ nanoparticles via sol-gel technique. Appl. Nanosci. $5 \quad$ (2015) 449-456. https://doi.org/10.1007/s13204-014-0337-y.

[75] N. Selvi, S. Sankar, K. Dinakaran, Effect of shell $\mathrm{ZnO}$ on the structure and optical property of $\mathrm{TiO}_{2}$ core@shell hybrid nanoparticles, J. Mater. Sci.: Mater. Electron. 26 (2015) 2271-2277. https://doi.org/10.1007/s10854-015-2680-5.

[76] M. Thomas, G.A. Naikoo, M.U.D. Sheikh, M. Bano, F. Khan, Effective photocatalytic degradation of congo red dye using alginate/carboxymethyl cellulose $/ \mathrm{TiO}_{2}$ nanocomposite hydrogel under direct sunlight irradiation, J. $\begin{array}{lllll}\text { Photochem. } & \text { Photobiol. } & \text { A. } & 327 & \text { (2016) }\end{array}$ https://doi.org/10.1016/j.jphotochem.2016.05.005.

[77] N.Q.T. Ton, T.N.T. Le, S. Kim, V.A. Dao, J. Yi, T.H.T. Vu, High-efficiency photo-generated charges of $\mathrm{ZnO} / \mathrm{TiO}_{2}$ heterojunction thin films for photocatalytic and antibacterial performance, J. Nanosci. Nanotechnol. 20 (2020) 2214-2222. https://doi.org/10.1166/jnn.2020.17306.

[78] W. Sun, S. Meng, S. Zhang, X. Zheng, X. Ye, X. Fu, S. Chen, Insight into the tranfer mechanisms of photogenerated carriers for heterojunction photoocatalyst with analogous position of valence band and conduction band: a case study of $\mathrm{ZnO} / \mathrm{TiO}_{2}$, J. Phys. Chem. C. 122 (27) (2018) 15409-15420. https://doi.org/10.1021/acs.jpcc.8b03753.

[79] A. Das, P.M. Kumar, M. Bhagavathiachari, R.G. Nair, Hierarchical ZnO-TiO 2 nanoheterojunction: a strategy driven approach to boost the photocatalytic performance through the synergy of improved surface area and interfacial charge 
transport, $\quad$ Appl. $\quad$ Surface $\quad$ Sci. $\quad 534 \quad$ (2020) 147321. https://doi.org/10.1016/j.apsusc.2020.147321.

[80] A.E. Mragui, I. Daou, O. Zegaoui, Influence of the preparation method and $\mathrm{ZnO} /\left(\mathrm{ZnO}+\mathrm{TiO}_{2}\right)$ weight ratio on the physicochemical and photocatalytic properties of ${\mathrm{ZnO}-\mathrm{TiO}_{2}}_{2}$ nanomaterials, Catal. Today 321 (2019) 41-51. https://doi.org/10.1016/j.cattod.2018.01.016.

[81] M. Kwiatkowski, R. Chassagnon, O. Heintz, N. Geoffroy, M. Skompska, I. Bezverkhyy, Improvement of photocatalytic and photoelectrochemical activity of $\mathrm{ZnO} / \mathrm{TiO}_{2}$ core/shell system through additional calcination: insight into the mechanism, Appl. Catal. B: Environ. $204 \quad$ (2017) 200-208. https://doi.org/10.1016/j.apcatb.2016.11.030.

[82] C. Wang, X. Li, N. Xia, M. Jiang, R. Liu, J. Huang, Q. Li, Z. Luo, L. Liu, W. Xu, D. Fan, Novel $\mathrm{ZnO}-\mathrm{TiO}_{2}$ nanocomposite arrays on $\mathrm{Ti}$ fabric for enhanced photocatalytic application, J. Molec. Struct. $1148 \quad$ (2017) 347-355. https://doi.org/10.1016/j.molstruc.2017.07.030.

[83] P.G. Ramos, E. Flores, L.A. S'anchez, R.J. Candal, M. Hojamberdiev, W. Estrada, J. Rodriguez, Enhanced photoelectrochemical performance and photocatalytic activity of $\mathrm{ZnO} / \mathrm{TiO}_{2}$ nanostructures fabricated by an electrostatically modified electrospinning, Appl. Surface Sci. $426 \quad$ (2017) 844-851. https://doi.org/10.1016/j.apsusc.2017.07.218. 
Figures

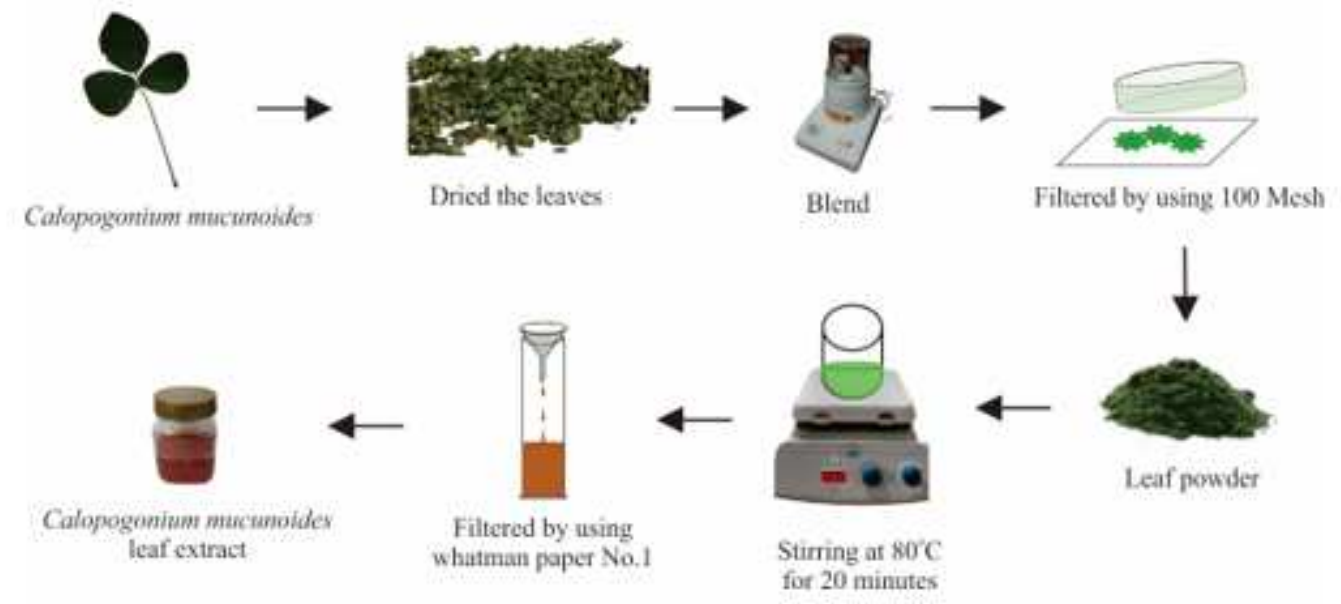

\section{Figure 1}

Schematic illustration for extraction of Calopogonium mucunoides leaves

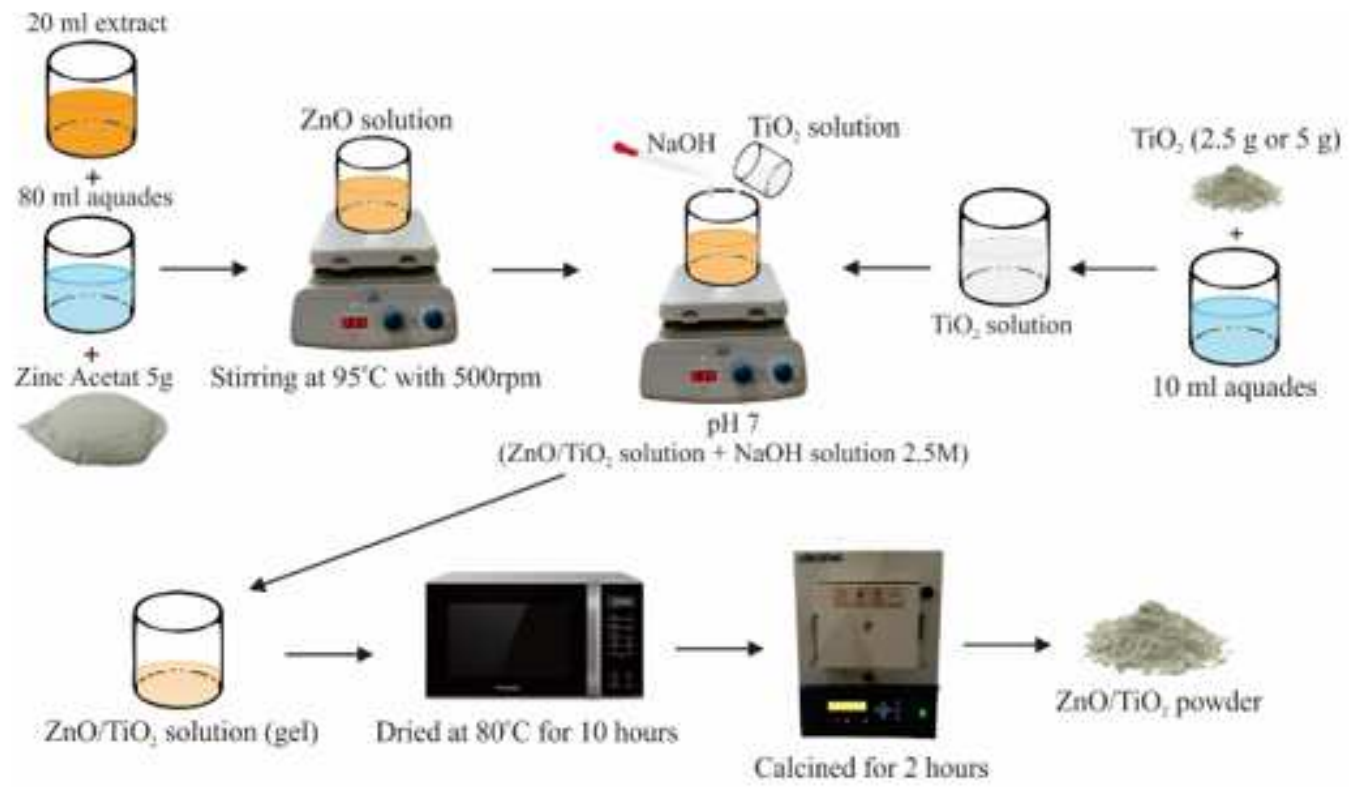

Figure 2

Illustration procedure of green synthesis $\mathrm{ZnO} / \mathrm{TiO} 2$ using Calopogonium mucunoides leaf extract 


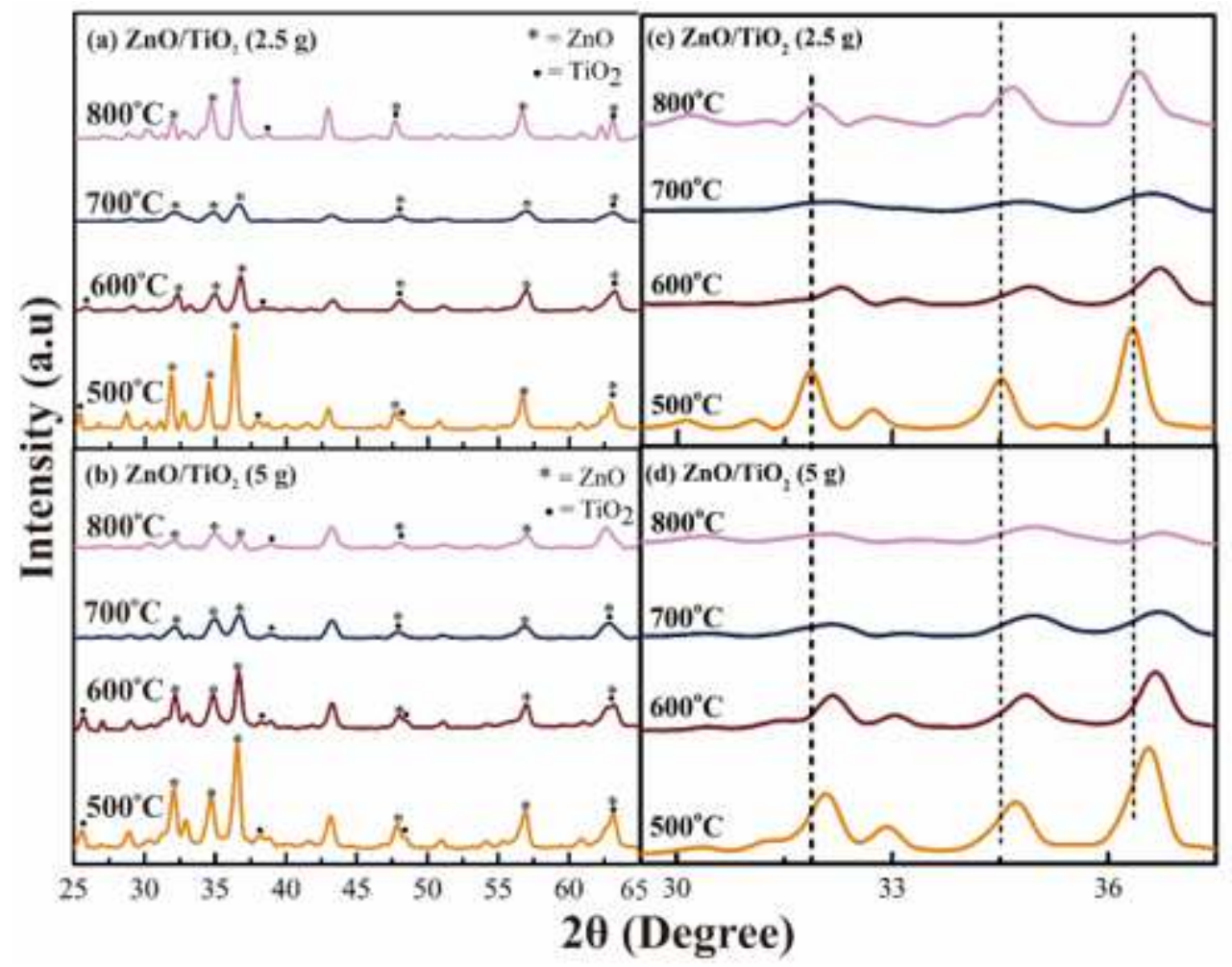

Figure 3

$\mathrm{XRD}$ analysis of $\mathrm{ZnO} / \mathrm{TiO} 2$ synthesized from Calopogonium mucunoides leaves extract for various calcination temperature $(500 \mathrm{oC}, 600 \mathrm{oC}, 700 \mathrm{oC}, 800 \mathrm{oC})$ and TiO2 concentration $(2.5 \mathrm{~g}$ and $5 \mathrm{~g})$ 


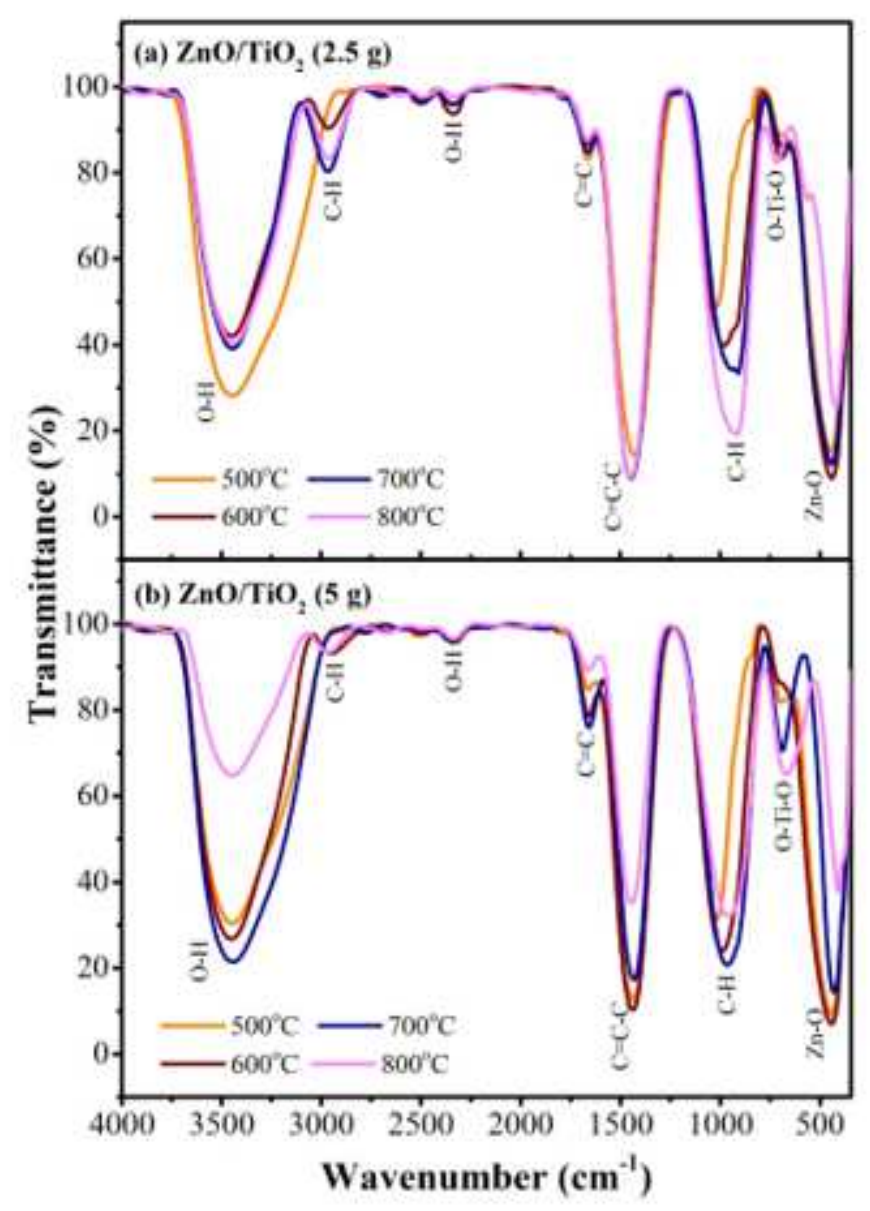

Figure 4

FTIR spectra of $\mathrm{ZnO} / \mathrm{TiO} 2$ synthesized from Calopogonium mucunoides leaves extract for various calcination temperature $(500 \mathrm{oC}, 600 \mathrm{oC}, 700 \mathrm{oC}, 800 \mathrm{oC})$ and TiO2 concentration $(2.5 \mathrm{~g}$ and $5 \mathrm{~g})$ 
(a)

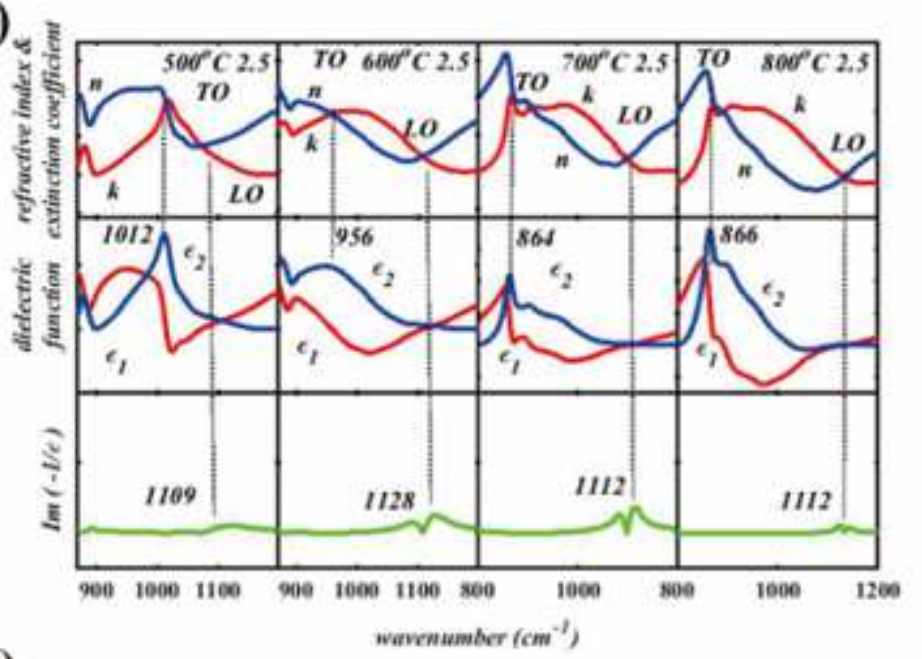

(b)

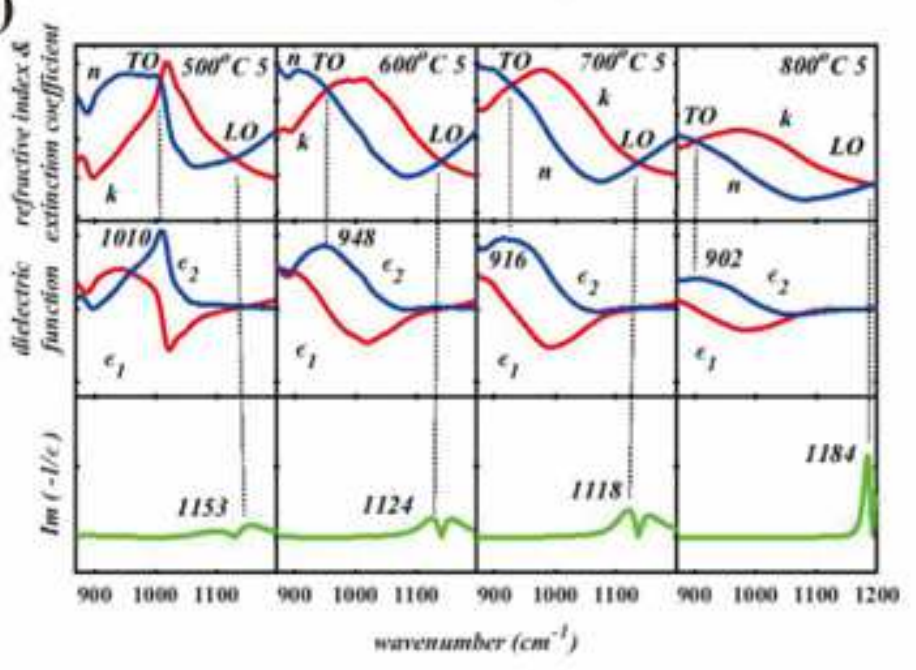

Figure 5

The optical properties (refractive index (n) and extinction coefficient $(k)$ ) determined from the FTIR spectra in Figure 4, from the optical properties the dielectric function, the energy loss function $\operatorname{Im}(-1 /$ $\varepsilon 1(\omega))$ are determined for various calcination temperature for (a) $\mathrm{ZnO} / \mathrm{TiO} 2(2.5 \mathrm{~g})$ and (b) $\mathrm{ZnO} / \mathrm{TiO} 2(5$ g). 


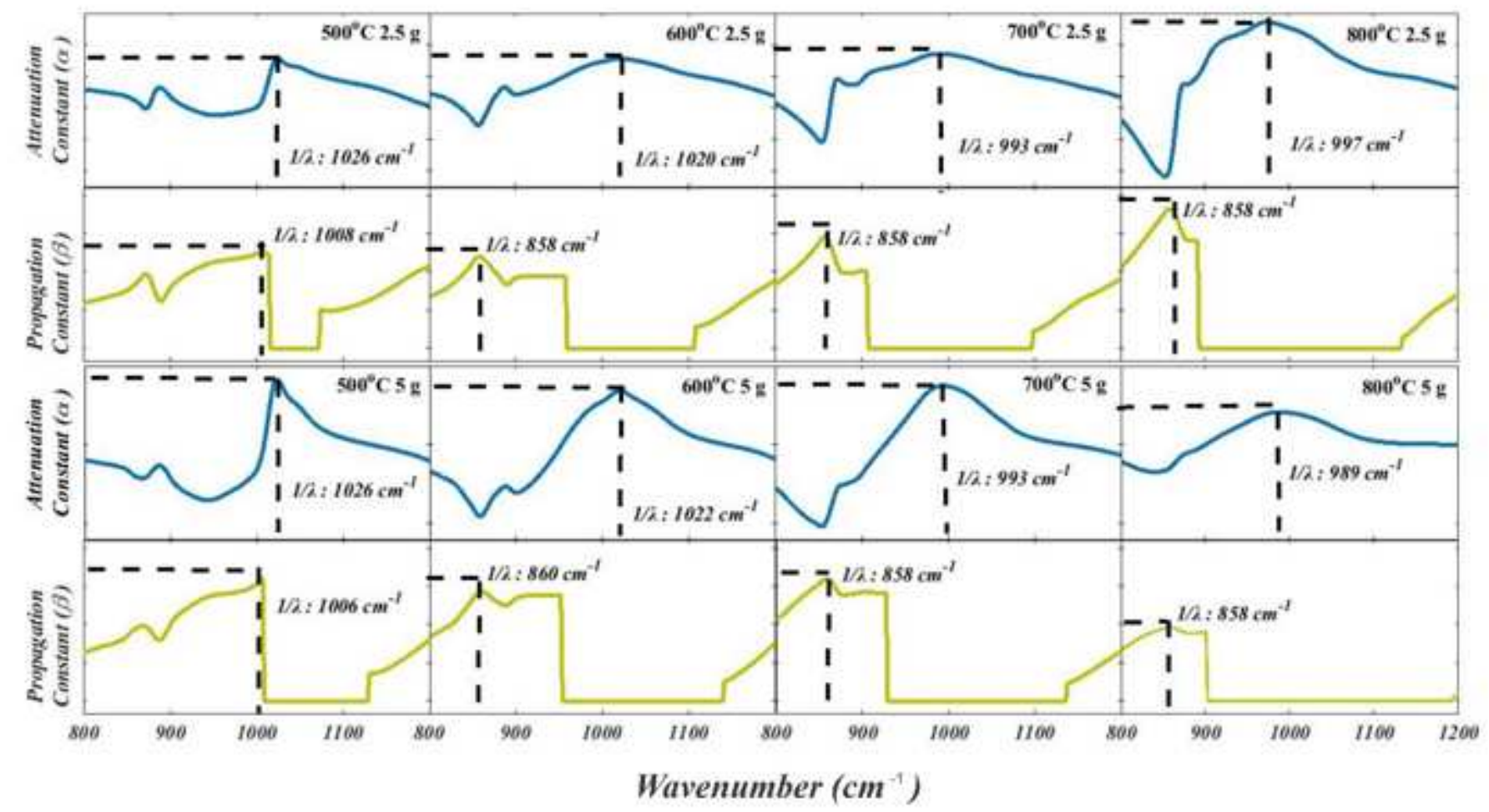

\section{Figure 6}

Attenuation constant ( $\mathrm{a}$ ) (first and third rows) and propagation constant ( $\beta$ ) (second and fourth rows) as a function of the wavenumber for calcination temperature from $500 \mathrm{oC}$ (left) to $800 \mathrm{oC}$ (right). First and second rows for $2.5 \mathrm{gr}$ of $\mathrm{TiO} 2$ in $\mathrm{ZnO} / \mathrm{TiO} 2$ composite and the third and fourth rows for $5 \mathrm{gr}$ of $\mathrm{TiO} 2$ in $\mathrm{ZnO} / \mathrm{TiO} 2$ composite. 


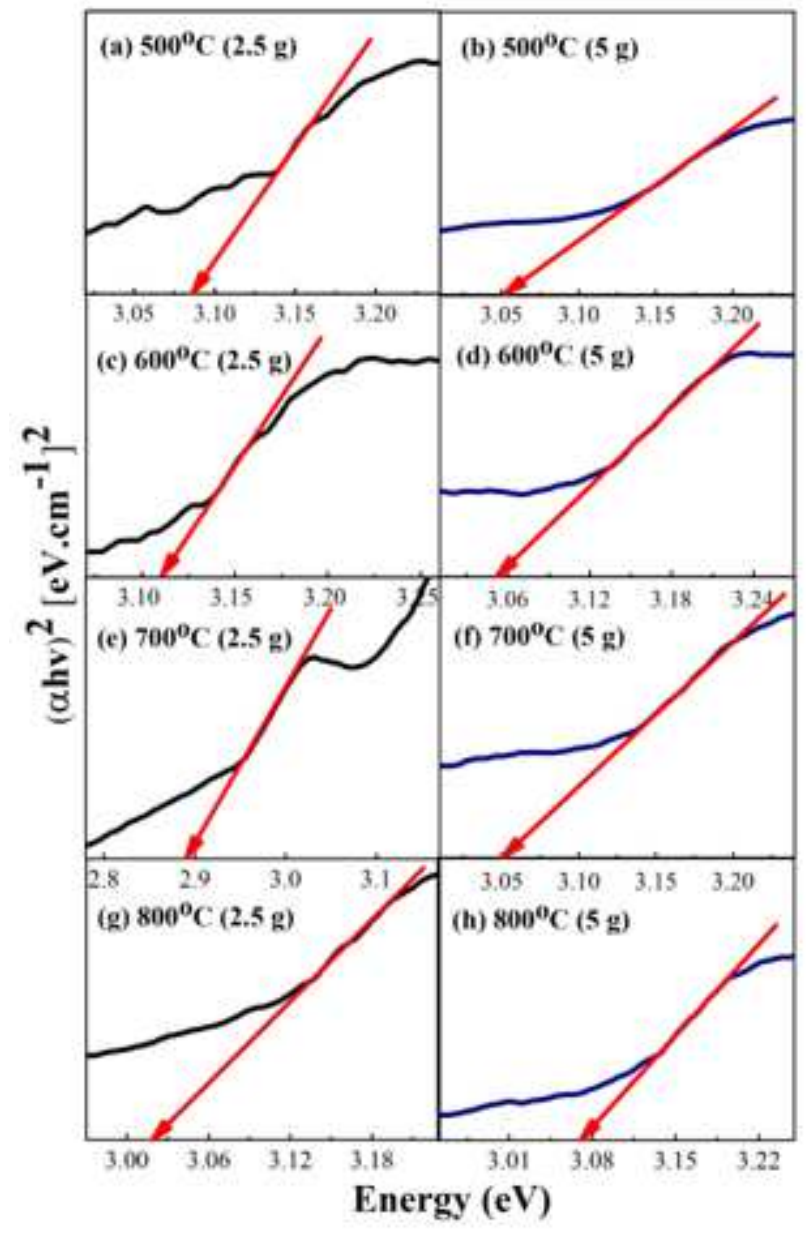

Figure 7

Band gap of $\mathrm{ZnO} / \mathrm{TiO} 2$ synthesized from Calopogonium mucunoides leaves extract for various calcination temperature $(500 \mathrm{oC}, 600 \mathrm{oC}, 700 \mathrm{oC}, 800 \mathrm{oC})$ and TiO2 concentration $(2.5 \mathrm{~g}$ and $5 \mathrm{~g})$ 


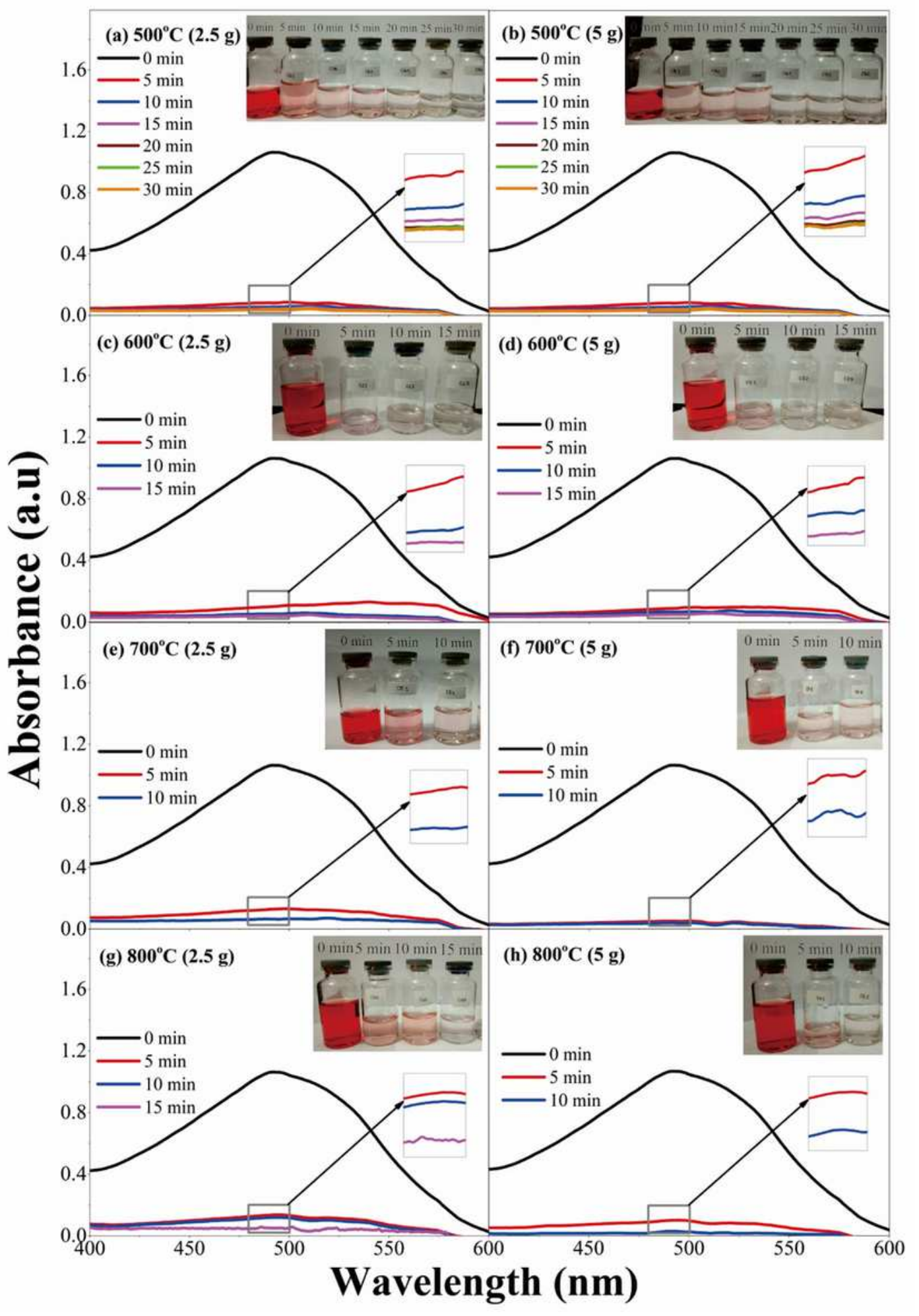

\section{Figure 8}

UV-visible absorption spectra of $\mathrm{ZnO} / \mathrm{TiO} 2(2.5 \mathrm{~g}$ and $5 \mathrm{~g})$ synthesized from Calopogonium mucunoides leaves extract for various calcination temperature $(500 \mathrm{oC}, 600 \mathrm{oC}, 700 \mathrm{oC}$, and $800 \mathrm{oC})$ 

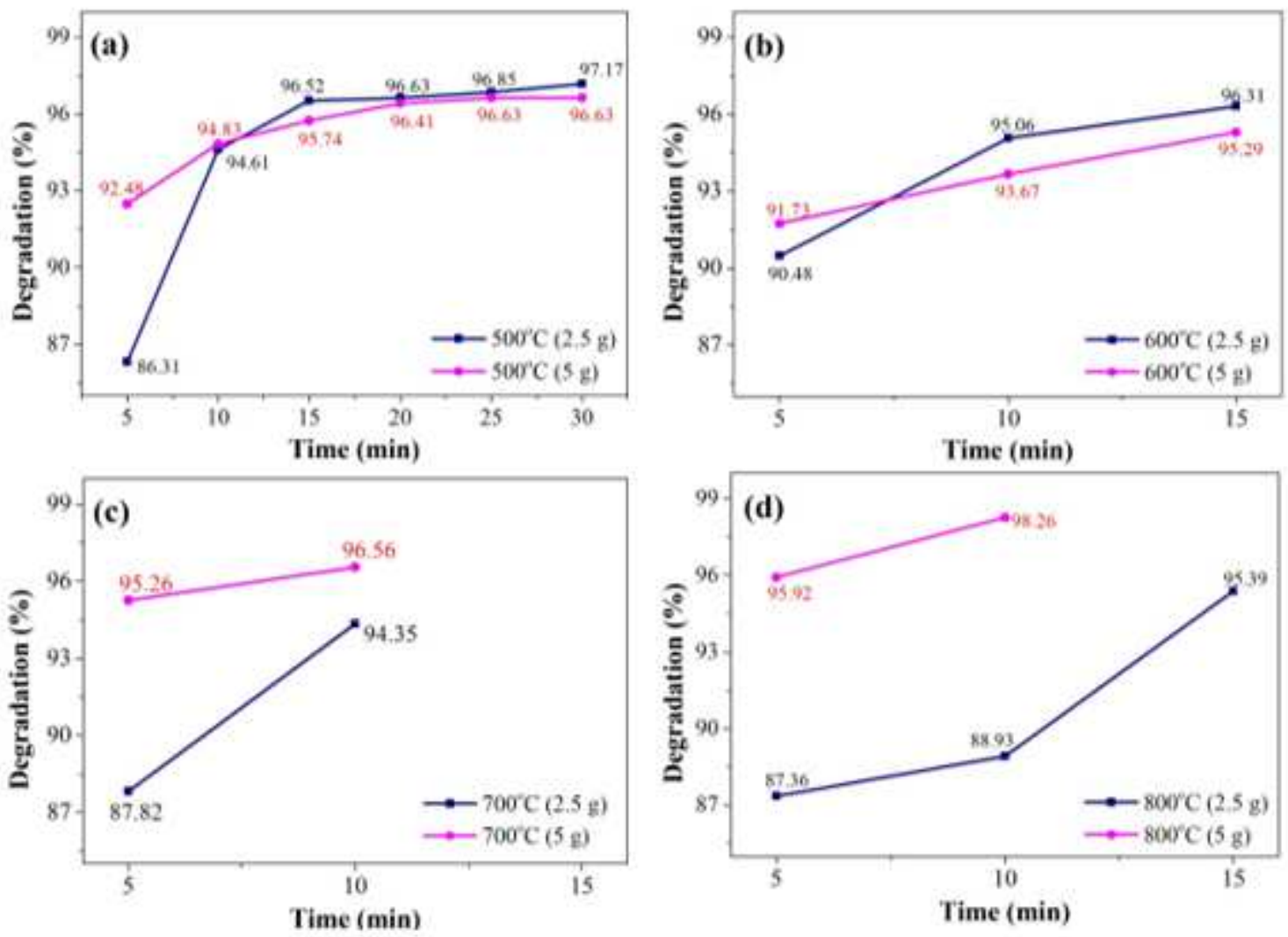

Figure 9

Percentage degradation of CR with the different catalysts (a) $500 \circ \mathrm{C}$, (b) $600 \circ \mathrm{C}$, (c) $700 \circ \mathrm{C}$, and (d) $800 \circ \mathrm{C}$

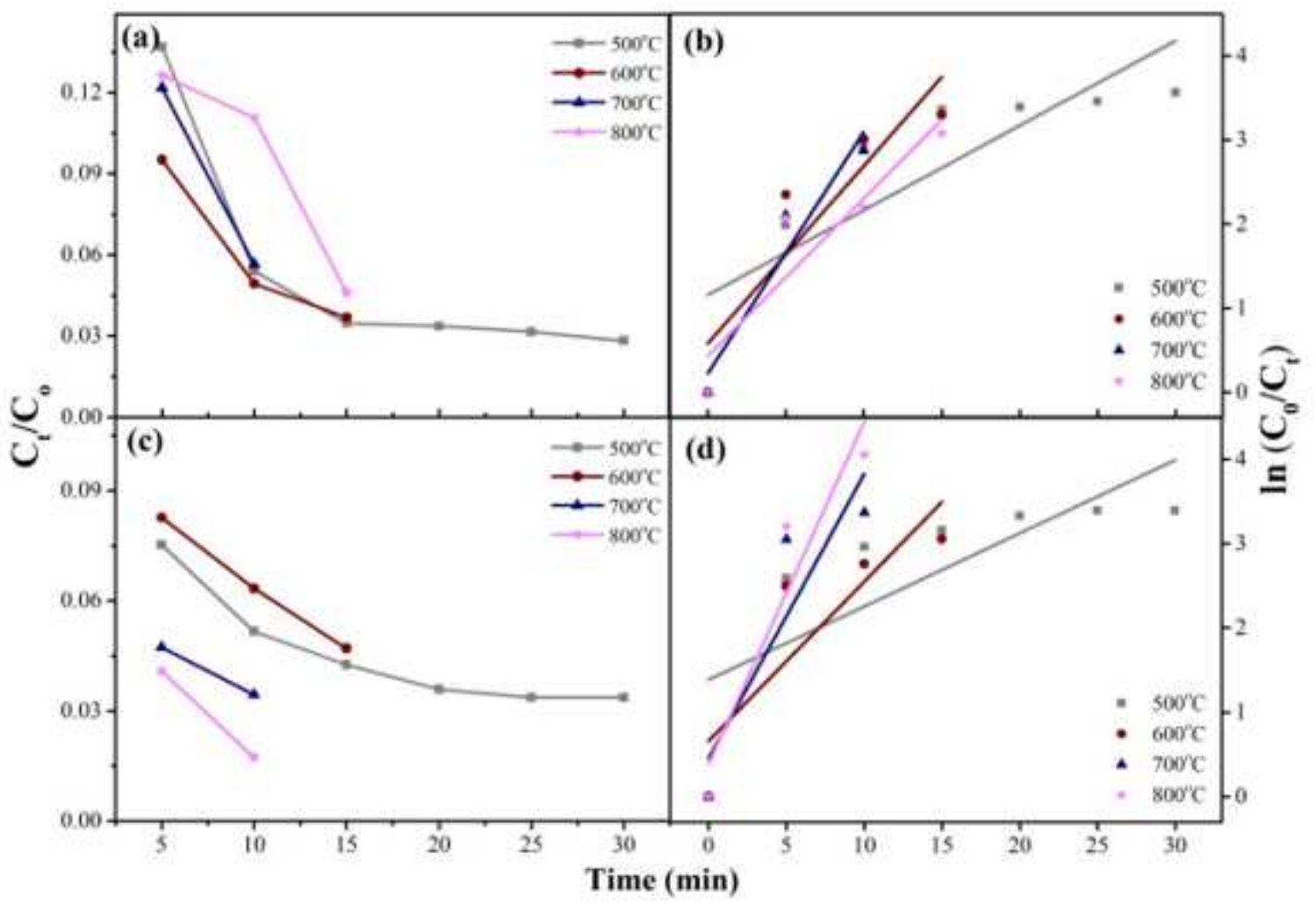


Figure 10

Photocatalytic performance and kinetic model of composites (a-b) ZnO/TiO2 (2,5 g) and (c-d) ZnO/TiO2 $(5 \mathrm{~g})$ for various calcination temperature in CR solution

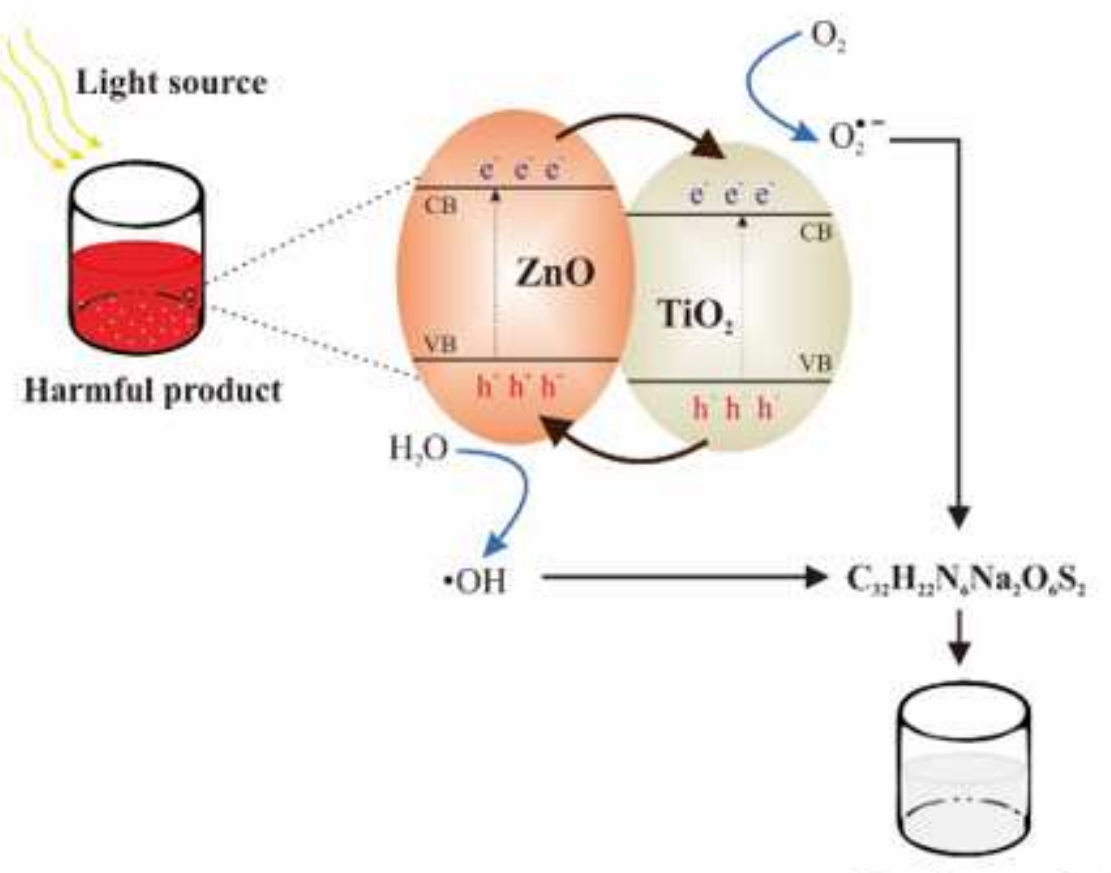

Harmless product

\section{Figure 11}

Schematic degradation process of $\mathrm{CR}$ from the incoming photon, transfer charge (electron and hole), produce radicals to break the bond of $\mathrm{CR}$, and the final product of photocatalytic in the composite $\mathrm{ZnO} / \mathrm{TiO} 2$ 


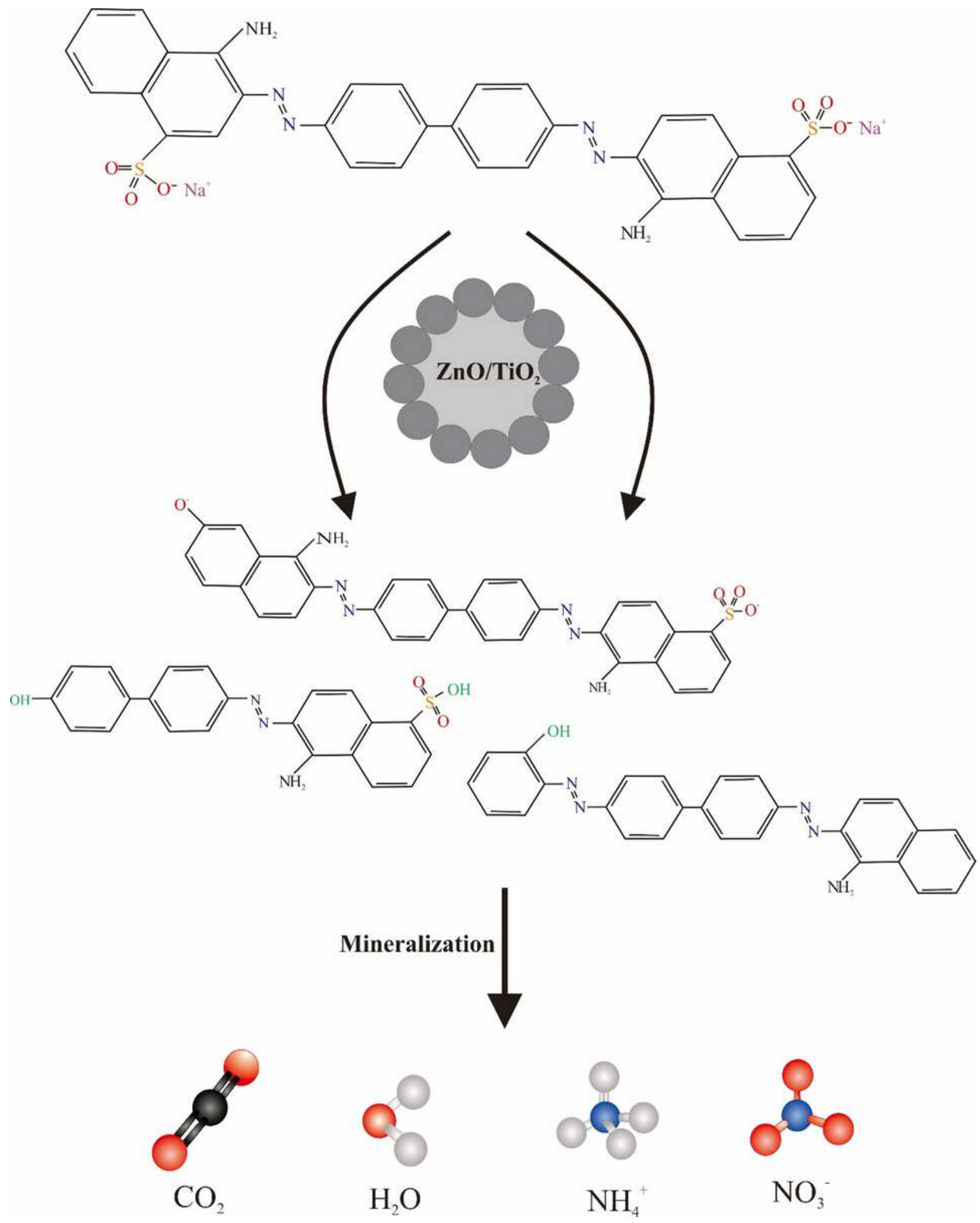

Figure 12

Demineralization mechanism of $\mathrm{CR}$ by the composite $\mathrm{ZnO} / \mathrm{TiO} 2$ in the photodegradation process 


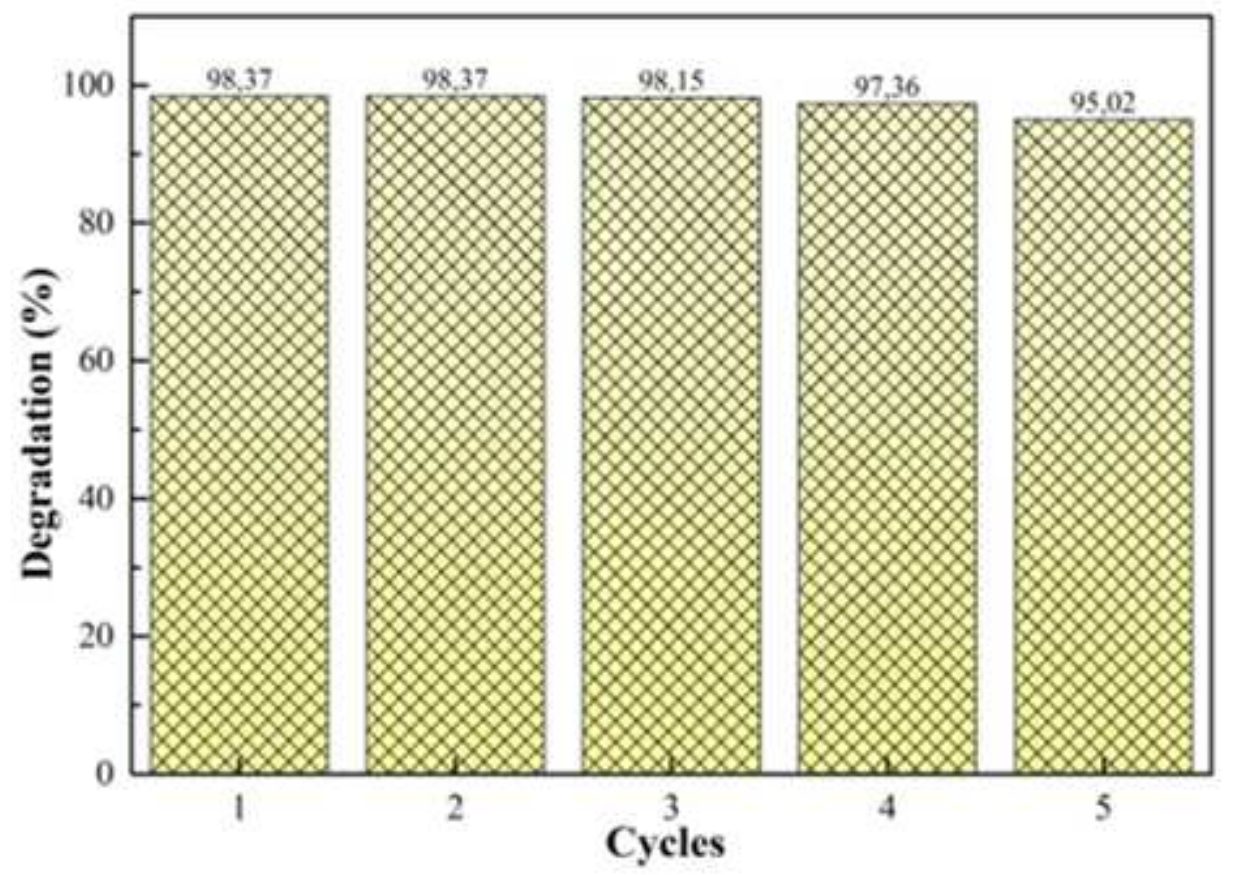

Figure 13

Stability degradation performance of composite $\mathrm{ZnO} / \mathrm{TiO} 2$ for $\mathrm{CR}$ dye up to five times 